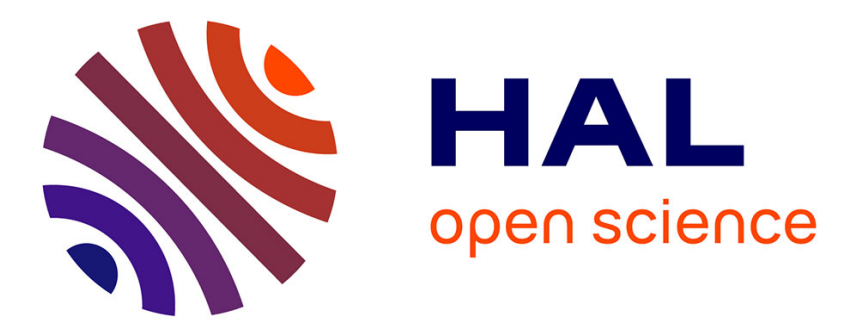

\title{
Syn-collisional channel flow and exhumation of paleoproterozoic High Pressure rocks in the Trans-North China Orogen: the critical role of partial-melting and orogenic bending
}

Pierre Trap, Michel Faure, Wei Lin, Romain Augier, Antoine Fouassier

\section{To cite this version:}

Pierre Trap, Michel Faure, Wei Lin, Romain Augier, Antoine Fouassier. Syn-collisional channel flow and exhumation of paleoproterozoic High Pressure rocks in the Trans-North China Orogen: the critical role of partial-melting and orogenic bending. Gondwana Research, 2011, 20, pp.498-515. 10.1016/j.gr.2011.02.013 . insu-00576322

\section{HAL Id: insu-00576322}

https://hal-insu.archives-ouvertes.fr/insu-00576322

Submitted on 24 Jun 2011

HAL is a multi-disciplinary open access archive for the deposit and dissemination of scientific research documents, whether they are published or not. The documents may come from teaching and research institutions in France or abroad, or from public or private research centers.
L'archive ouverte pluridisciplinaire HAL, est destinée au dépôt et à la diffusion de documents scientifiques de niveau recherche, publiés ou non, émanant des établissements d'enseignement et de recherche français ou étrangers, des laboratoires publics ou privés. 
Syn-collisional channel flow and exhumation of paleoproterozoic High Pressure rocks in the Trans-North China Orogen: the critical role of partial-melting and orogenic bending.

Pierre Trap $^{\mathrm{a}, *}$, Michel Faure ${ }^{\mathrm{b}}$, Wei Lin ${ }^{\mathrm{c}}$, Romain Augier ${ }^{\mathrm{b}}$, Antoine Fouassier $^{\mathrm{b}}$

${ }^{\text {a } U M R-C N R S ~} 6249$ Chrono-Environnement, Université de Franche-Comté, 16 route de Gray 25030 Besançon cedex, France.

${ }^{\mathrm{b}}$ Institut des Sciences de la Terre d'Orléans, CNRS Université d'Orléans (UMR 6113), 45067 Orléans Cedex 2, France.

${ }^{\mathrm{c}}$ State Key Laboratory of Lithospheric Evolution, Institute of Geology and Geophysics, Chinese Academy of Sciences, Beijing 100029, China.

* Corresponding author. Tel.: +33 (0)3 81666431 ; fax : +33 (0)3 81666558 ; E-mail address: pierre.trap@univ-fcomte.fr

\section{Abstract}

Within the paleoproterozoic Trans-North China Orogen, the High-Pressure Belt (HPB) is made of high-pressure ( $\sim 15 \mathrm{kbar})$ mafic granulites hosted in migmatitic gneisses. In this contribution, we document a set of structural analyses acquired over the whole HPB. We also proposed a morphological subdivision of the partially molten rocks that compose the HPB according to changes in melt fraction. A compilation of the P-T and radiochronological data carried out over the last 15 years is presented. The results highlight the concurrent effect of oroclinal bending and partial-melting in controlling the exhumation of the deeply buried continental crust. 
During ongoing compression of the thickening orogenic root, onset of partial-melting at peak metamorphism is responsible for a first strength drop that enhanced an eastward lateral flow. Radiometric ages show that the deep crust was partially molten over a $50 \mathrm{Ma}$ lasting period during which it evolved in a diatexite core mantled by metatexites. This was responsible for a second strength drop with strain concentrated along the diatexite/metatexite boundaries, as exemplified by the newly documented Datong-Chengde Shear Zone, a 400 km-long normal shear zone with a sinistral strike-slip component that accommodated the final uprise of the high-pressure rocks.

Keywords: High-pressure rocks; Exhumation; Partial melting; Channel flow; Trans-North China Orogen.

\section{Introduction}

Paleoproterozoic high-pressure metamorphic rocks buried to depth exceeding $50 \mathrm{~km}$, and exhumed to shallow crustal levels are extremely rare all over the world (O'Brien and Röttzler, 2003). Such old high-pressure rocks are very precious since the understanding of their structural and metamorphic evolution brings insights about orogenic processes during the Paleoproterozoic, and more generally about flow and exhumation mechanisms of thickened orogenic continental crust. Unfortunately the mechanisms responsible for the exhumation of such rare old high-pressure rocks are quite difficult to settle since the structural and metamorphic evidences have commonly been reworked during subsequent younger orogenies.

For the purpose of our study, the High-Pressure Belt (HPB) of the Trans-North China Orogen (TNCO) is of particular interest because (1) high-pressure mafic granulites (including 
retrograded eclogites) with isothermal decompression paths have been largely reported along the whole belt (e.g. Zhang et al., 2006), (2) younger reworking processes are weak in this area of the North China Craton, (3) outcrop conditions allow a detail geometric and kinematic study over the entire HPB, and (4) the regional architecture and evolution of the TNCO are presently relatively well understood.

As for numerous high-pressure belts over the world, the TNCO High-Pressure Belt is mainly made of partially-molten rocks (migmatites) within which retrograded eclogites and HP-granulites occur. Partial-melting changes rock rheology and density, and is therefore a critical phenomenon in exhumation of deep-seated crust. In particular, the viscosity drop commonly attributed to partial-melting is responsible for continental crust to flow since it can no longer support the weight of the wedge (Vanderhaeghe et al., 2003). This concept is well known as channel flow (Beaumont et al., 2001, 2004, 2006; Jamieson et al., 2004, 2006; Grujic, 2006). Recently, Vanderhaeghe (2009) inventories the various modes of flow of partially-molten orogenic continental crust and distinguishes the vertical channel flow driven by plate tectonic related forces and the horizontal channel flow related to the gravity force associated with lateral change in crustal thicknesses. A large number of conceptual models have been proposed to account for channel flow and exhumation of lower crust in collisional orogens (Beaumont et al., 2001, 2004, 2006; Jamieson et al., 2004, 2006; Gervais and Brown, 2011; Rey et al., 2010). In each model a particular tectonic setting is advocated such as, for instance, upper-crustal extension, active erosion, retreat of the foreland, under-thrusting or orogenic wedge shortening. Overall, mode of flow and exhumation of lower crust comes from a balance between gravity and boundary forces, which is specific to each orogenic belt.

In spite of numerous petrological and geochronological studies conducted on the highpressure granulites and surrounding rocks of the $\mathrm{TNCO}$, the tectonic processes, and especially the crustal structure and flow pattern involved in the exhumation of the high pressure and 
partially-molten rocks remain unclear and constitute the topic of this paper. For the first time, we document a set of structural analyses acquired on the entire High Pressure Belt. This was conducted together with recognition of morphological subdivisions of the partially molten rocks according to changes in melt fraction. In addition, we present a new compilation of the available Pressure-Temperature paths and geochronological data. A synthetic model allows us to discuss the unroofing processes of the High-Pressure Belt (HPB) and to highlight the critical role of partial-melting and oroclinal bending in triggering and controlling lateral extrusion through channelized flow and exhumation of the deeply buried continental crust.

\section{The High-Pressure Belt within the Trans-North China Orogen}

\subsection{Tectonic outline of the Trans-North China Orogen within the North China Craton}

A long-established three-fold subdivision describes the North China Craton (NCC) as composed of the two Archean-Paleoproterozoic Eastern and Western Blocks separated by the -1.85 Ga Trans-North China Orogen, also named Central Orogenic Belt (Fig. 1; Zhao et al., 2001a-b). Thoroughly, the Western Block is composed of two discrete sub-blocks labelled the Ordos and Yinshan Blocks welded together along the Khondalite Belt around 1.95-1.92 Ga (Zhao et al., 2005, 2010; Santosh et al., 2006, 2007a,b; Yin et al., 2007, 2009, 2011). The Eastern block is divided in the Southern Block and the Anshan Block that welded together along the Jiao-Liao-Ji mobile belt at $\sim 1.9 \mathrm{Ga}$ (Faure et al., 2004; Li and Zhao, 2007).

The High-Pressure Belt lies within the $1200 \mathrm{~km}$ long and $100-300 \mathrm{~km}$ wide TransNorth China Orogen (TNCO) (Fig. 1). According to different schools of thought, the TNCO resulted from (1) continental collision at $\sim 1.85 \mathrm{Ga}$ after an eastward subduction of the Western Block below the Eastern Block (Zhao et al., 2001a-b, 2004, 2005; Wilde et al., 2005; 
Kröner et al., 2005a-b, 2006; Zhang et al., 2006), (2) a westward subduction with final collision to form the NCC at $\sim 2.5 \mathrm{Ga}$ (Kusky and Li, 2003; Polat et al., 2005, 2006; Kusky et al., 2007; Li and Kusky, 2007) or at 1900-1800 Ma (Wang, 2009) and otherwise (3) a collision after a double-sided subduction (Santosh, 2010).

Faure et al. (2007) and Trap et al. (2007, 2008, 2009a, 2009b) proposed a model in which the building of the TNCO involved three continental blocks, two westward subduction zones and associated two collisional events. The eastern positioned suture is called the Zanhuang suture (Faure et al., 2009, Trap et al., 2009) that resulted from westward subduction of the Eastern (Yanliao) Block under the Fuping Block (Fig. 1B; Faure et al., 2007; Trap et al., 2009). Faure et al. (2007) propose that the amalgamation of the Fuping Block and the Eastern Block occurred at $\sim 2.1 \mathrm{Ga}$. The western suture, called the Trans-North China Suture that crop out in the Lüliangshan massif, marked the closure, at around $1880 \mathrm{Ma}$, of an oceanic domain called the Lüliang Ocean (Fig. 1B; Faure et al., 2007; Trap et al., 2007, 2009a-b). This suture is the main lithospheric boundary along which ophiolitic and continental crustderived nappes, displaced to the East or South-East, are rooted, resulting in the edification of the Trans-North China Orogen (TNCO) where HP rocks crop out.

The TNCO consists of several tectonic and metamorphic units (Fig. 1B; Faure et al., 2007, Trap et al., 2007). At the top of the litho-tectono-metamorphic pile, the Hutuo Supergourp (SBGMR, 1989; Tian, 1991) consists of unmetamorphozed or weakly metamorphosed, locally highly deformed sedimentary series of conglomerate, sandstone, mudstone, and carbonates with subordinate intercalations of volcanic rocks. It unconformably cover the Low-Grade Mafic Unit (LGMU) that represents greenschists facies klippen of mafic magmatic and sedimentary rocks emplaced from the NW to the SE upon the Orthogneiss and Volcanite Unit (OVU) made of magmatic and volcanic-sedimentary rocks metamorphosed under amphibolite to MP-granulite facies conditions. The OVU tectonically overlies a para- 
autochtonous unit that corresponds to the basement of the Fuping Block. The last unit recognized in the Trans-North China Orogenic wedge, and that is the focus of the present contribution, is the high-pressure rocks unit, referred as the High-Pressure Belt.

\section{[ Figure 1 ]}

\subsection{Geological setting of the High Pressure Belt (HPB)}

In the Trans-North China Orogen, high-pressure mafic and felsic granulites (Figs. 2A and 2B) crop out in a NE-SW trending unit of $150 \mathrm{~km}$ wide and $400 \mathrm{~km}$ long belt (Fig. 1B), referred as the High-Pressure Belt (HPB) that extends from the northern part of the Hengshan Massif (Zhao et al., 2001a; O'Brien et al., 2005), through the Datong-Huai'an area (Zhai et al., 1992, 1995; Guo et al., 1993, 2002) and Xuanhua Massif (Wang et al., 1994; Guo et al., 2002), up to the Chengde Massif (Li et al., 1998; Mao et al., 1999). Within the HPB, the average foliation strike progressively changes from N70E to the East to N45E to the West (Fig. 1B). Two major ductile shear zones, the Zhujiafang (Li and Qian, 1994) and the Datong-Chengde Shear Zones (this study) limit the HPB along its southern and northern boundaries, respectively (Fig. 3A). The high-grade metamorphic rocks of the HPB are unconformably covered by Meso- to Neoproterozoic and Jurassic-Cretaceous unmetamorphosed sedimentary or volcanic rocks and intruded by several generations of granitoids, mainly of Mesozoic age. Consequently, the western and eastern terminations of both shear zones and the structural relationships of the HPB with the southeastern orthogneiss-volcanite unit remain unknown.

\section{[ Figure 2 ]}


The HPB consists mainly of anatectic rocks with granulitic boudins that recorded a clockwise P-T retrograde evolution, characterized by an isothermal decompression from 15 kbar to 5 kbar (e.g. Zhang et al., 2006). Lithological and metamorphic characters are presented in detail in the next sections.

Northwest of the HPB, high temperature Al-rich metasediments crop out that belong to the 'Khondalite series' of the Chinese literature which is considered to have developed in the passive continental margin of the Ordos Terrane of the Western Block (Condie et al., 1992; Zhao et al. 1998, 2005; Kusky et al., 2007). To the east, these rocks are underlain by TTG rocks that form the northern domains of the Xuanhua and Chengde massifs, north of the DCSZ (Fig. 1B). Along the DCSZ and the northern boundary of the HPB, blocks of hornblendite, metagabbro, pyroxenite and serpentinite are exposed, well observed in the western Huai'an Massif and eastern Chengde Massif. In this last area, these mafic and ultramafic rocks are involved in the Datong-Chengde Shear Zone (Figs. 5 and 7). Ophiolites are not cropping out in the Datong area and farther East. Nevertheless, the lithological, structural and metamorphic contrasts between the khondalite series and the high-pressure granulites suggest that this fault represents the northeastward extension of the Trans-North China suture east of Datong. These mafic and ultramafic rocks might be considered as the remnants of the Lüliang Ocean.

As a whole, the HPB appears as the deepest part of the thickened crust that was exhumed and that occupies a peculiar position in the core of an oroclinal bend experienced by the TNCO. Indeed, the orocline is well marked by the change in strike of the Paleoproterozoic planar fabrics that progressively turns from N20E to N70E, from the south-western Lüliang Massif toward the north-eastern Chengde Massif, respectively (Fig. 1B).

The regional deformation history of the westernmost part of the HPB, has been 
investigated by Zhang et al. (1994) in the Datong-Huai'an area. These authors inferred a deep-seated low-angle ductile extensional detachment as the main structure responsible for the exhumation of the high-pressure granulites. Because of a lack of unequivocal kinematic indicators, Dirks et al. (1997) did not took into consideration such a detachement fault and suggested that the exhumation of the HP rocks was not accommodated by orogenic extensional tectonics. They rather advocated a dynamic interplay between solid-state vertical flow and horizontal flattening, in lower and upper structural domains, respectively. These two studies focused on the westernmost edge of the HPB (i.e. the Datong-Huai'an area), but no structural work has been done in the entire HPB. In particular, the geometric and kinematic features of the central and eastern parts of the HPB were not analyzed. Furthermore, the tectonic evolution of the HPB as a whole has never been considered. In order to get a general structural view of the HPB, the western Datong-Huai'an area, the central Xuanhua massif and the eastern Chengde massif were the targets of a detail structural analysis. In addition, we present a morphological subdivision of the HPB and its surrounding rocks based on observation of changes in melt fraction (mainly diatexite/metatexite distinction).

\section{The HPB within the Partially Molten Zone (PMZ)}

The HPB is mainly composed of partially-molten rocks (Fig. 2) and lies within a here defined Partially Molten Zone (PMZ). Within the PMZ, a four-fold subdivision from lower to upper structural level is recognized: These four anatectic subunits namely from bottom to top (1) The Lower Mafic Metatexite, (2) The Middle Diatexite, (3) The Upper Metatexite and (4) the Outer Metatexite. This subdivision is primarily a morphological one based on the melt fraction in the migmatitic rocks, mainly diatexite/metatexite disctinction. Metatexite and diatexite represent rocks with low and high melt fraction, respectively (Sawyer, 2008). 


\subsection{The Lower Mafic Metatexite}

Structurally, the Lower Metatexite represents the deepest domain that crops out in the central part of the HPB, i.e. in the southern part of the Xuanhua Massif and the easternmost part of the Datong-Huai'an area (Fig. 5 and 6). The lowermost part is composed of banded tonalitic and mafic granulite gneiss. The pre-melting structures of the protolith are well preserved and the weak amount of leucosome argues for a low melt fraction (Fig. 2A). This apparently low melt fraction might not be due to a low-melting rate but rather to melt loss, as suggested by low leucosome to peritectic garnet ratios (Sawyer, 2008).

\subsection{The Middle Diatexite}

The Middle Diatexite is composed of granitoids of various compositions. The lower part is dominated by orthopyroxene-bearing granitoids (charnokite-enderbite suite) with subordinate amounts of dioritic granitoids. The upper part of the Middle Diatexite is more felsic with predominant dioritic to granodioritic compositions. These granitoids are diatexites in the sense of Sawyer (2008) with leucocratic material enclosing boudins and rafts of retrograded HP granulites (Fig. 2B). Morphological aspects grade from scholen to schlieric diatexites (Figs. 2C and 2D). Some felsic biotite-garnet and sillimanite-garnet metasedimentary rocks also occur as meter-thick paleosome lenses enclosed within leucocratic neosome. In addition, numerous K-feldspar rich granitoids are reported as $\mathrm{cm}$ to m-thick veins and sheeted dykes that intrude within the diatexite. Sometimes, such K-feldspar rich granitoids form 10-meters large bodies particularly in the highest structural level of the Upper Metatexite. 


\subsection{The Upper Metatexite}

The Upper Metatexite is located in the uppermost part of the HPB, either in central position or along the DCSZ and the Zhujiafang Shear Zone. It mostly consists of partially molten TTG gneiss, mafic and felsic metavolcanites and sometimes Al-rich metapelites and metacarbonaceous rocks (Figs. 2E, 4A and 4B).

\subsection{The Outer Metatexite}

These rocks crop out in two distinct areas, on each sides of the HPB (Fig. 8). North of the HPB, from Xuanhua area to Chengde area, TTG and migmatites widely develop. These partially melted rocks are metatexites developed from a khondalitic paleosome. Mafic and felsic metavolcanic rocks are also recognized as protoliths. The TTG and migmatites are conspiscuously intruded by numerous granitic dykes and sills. In the following, this unit will be referred to as the Northern Felsic Unit (Figs. 3 and 8). At the scale of the entire TNCO, the Northern Felsic Unit corresponds to the deformed and partially molten margin of the Western Block. The relationships of this unit with the Khondalite Unit that crops out northeast of Datong are unclear since the contact is not exposed in the field. Furthermore, south of the Zhujiafang Shear Zone or North of the Chendge-Datong Shear Zone, HP granulites are no more observed. Patch metatexite (Sawyer, 2008) with a very low-melt fraction (Fig. 2F) marks the limit of the partially molten area.

\section{Structural analysis}


Although in some places, the Meso- and Neoproterozoic sedimentary sequences are folded, or deformed by brittle faulting (Davis et al., 2005), no syn-metamorphic deformation younger than the Paleoproterozoic Trans-North China Orogeny can be documented in the study area, expect some reworking along portions of the western part of the DCSZ. Therefore, the ductile high-grade deformation described below can be confidently attributed to the Paleoproterozoic.

The HPB bulk geometry is an elongate asymmetric antiform with a gently northwarddipping northern limb, bounded by the Datong-Chengde shear zone, and a sub-vertical to steeply southward-dipping southern limb, limited by the Zhujiafang shear zone. The foliation pattern shows that the hinge zone of the antiform is curved in map view from E-W to NE-SW, and also in the vertical plane, with the eastern and western pericline terminations dipping toward the east and the west, in the Datong-Hua'ian and Chengde Massifs, respectively (Fig. 3). As a consequence, the central part of the HPB exposes the lower structural domain whereas the upper structural domain is observed in the eastern and western pericline terminations and along the two northern and southern bounding (Fig. 8).

Structural analysis yielded to the recognition of four main structural stages (labeled hereafter $\left.\mathrm{D}_{1}-\mathrm{D}_{4}\right)$, responsible for the structuration of the HPB and the Partially Molten zone as a whole. Details of each deformation stage are given below.

\section{1. $D_{1}$ Deformation stage}

Within the HPB rocks, the $\mathrm{D}_{1}$ fabric is an amphibolite facies gneissic foliation $\left(\mathrm{S}_{1}\right)$ recognized within the paleosomes. A $\mathrm{L}_{1}$ mineral lineation is often obliterated by a pervasive static recrystallisation. In diatexite, a pre-partial-melting $\mathrm{S}_{1}$ relictual fabric is preserved within the scattered schollen of paleosomes. In metatexite, $S_{1}$ and a syn-anatectic $S_{2}$ foliations are 
mingled in a $\mathrm{S}_{1-2}$ fabric, the geometry of which defines the $\mathrm{D}_{2}$ finite strain pattern (see below). The $\mathrm{D}_{1}$ fabric remains preponderant in the units that surround the PMZ, where partial-melting did not occurred, i.e. along the northern and southern limits of the PMZ, respectively. There, the conspicuous $\mathrm{D}_{1}$ fabric is a gneissic foliation $\mathrm{S}_{1}$ that trends NE-SW to E-W, on which a NW-SE trending mineral and stretching lineation, $\mathrm{L}_{1}$, marked by a preferred alignment of sillimanite, biotite or amphibole crystals develops (Fig. 3B). Along $\mathrm{L}_{1}$, a prominent top-to-the SE sense of shear is indicated by classical kinematic indicators, such as sigma-type porphyroclast systems or pressure shadows. In the commonest cases, reworking by the following $D_{2}$ to $D_{4}$ events led to the folding and scattering of the $D_{1}$ fabric trend.

[ Figure 3]

\section{2. $D_{2}$ Deformation stage}

\subsection{1. $\mathrm{D}_{2}$ strain features}

The $\mathrm{D}_{2}$ stage is the most prominent deformation stage developed in the PMZ, coevally with amphibolite to granulite facies metamorphism and crustal melting. $\mathrm{D}_{2}$ can be considered as a syn-anatectic deformation, in other words, the $\mathrm{D}_{2}$ migmatitic layered fabric was generated by in-situ melting and segregation of leucocratic material under a regional strain (Figs. 4A and 4B). As mentioned above, the $\mathrm{S}_{2}$ foliation is defined by leucocratic material that formed parallel to the early gneissic layering $\mathrm{S}_{1}$. Thus, the syn-anatectic foliation within metatexite has to be considered as a $\mathrm{S}_{1-2}$ fabric.

Within the Lower Mafic Metatexites, $\mathrm{S}_{2}$ is defined by the planar alignement of leucocratic melt pockets develop parallel to peritectic minerals as well as around retrograded 
matrix minerals. In some granitoids, such as the Huai'an anatectic charnokite (G.C. Zhao et al., 2008), the $\mathrm{S}_{2}$ foliation is represented by the preferred orientation of leucocratic orthopyroxene or clinopyroxene-bearing anorthositic veins (Dirks et al., 1997). In the Middle Diatexite, $\mathrm{S}_{2}$ is defined by biotite-amphibole schlierens and the preferred orientation of mafic restites (Figs. 2C and 3E).

The $\mathrm{L}_{2}$ mineral lineation is commonly marked by the linear preferred orientation of aggregates of peritectic minerals such as garnet, biotite or orthopyroxene. In leucocratic material, the $\mathrm{L}_{2}$ lineation is represented by stretched $\mathrm{mm}$ - to $\mathrm{cm}$-scale biotite or amphibole aggregates. However, the clearest and unambiguous observations of $\mathrm{L}_{2}$ in migmatites are made at the outcrop scale, where the stretching direction is defined by meter-scale boudinage of competent mafic paleosomes or melanosomes (Figs. 2C and 2D). Stretching is also documented by the orientation of tension gashes filled with granitic or charnokitic melt.

Along the $\mathrm{L}_{2}$ stretching direction, kinematic patterns are contrasted. A non-coaxial strain regime is deduced from the observation of kinematic criteria such as asymmetric boudinage, asymmetric sigma-type porphyroclast systems around peritectic minerals, or shear band. In addition, symmetric boudinage argues for coaxial flow. Over the entire PMZ, the $\mathrm{D}_{2}$ finite strain pattern can be subdivided into four spatially distinct areas: (1) the central part characterized by 10-50 km wide SW-NE trending domes deformed by a E-W coaxial flow; (2) the geometrically higher rim of the central part, (3) the western part of the HPB, that are both characterized by non-coaxial regime and (4) the folded outer metatexite in the Hengshan Massif.

[ Figure 4 ]

4.2.2. SW-NE to E-W trending coaxial flow and doming 
Within the HPB, the $\mathrm{S}_{2}$ geometry defines regional-scale dome structures that vary in size from 10 to $40 \mathrm{~km}$ in length and 5 to $20 \mathrm{~km}$ in width (Figs. 5, 6 and 7). Usually, $\mathrm{S}_{2}$ trends E-W in the central and eastern part of the HPB and NE-SW in its western edge (Fig. 3C). The attitude of the $\mathrm{S}_{2}$ foliation varies from nearly horizontal to vertical in the dome top and margins, respectively. However, neither vertical nor steeply dipping foliation occurs at dome terminations but only along the NE-SW to E-W trending dome limbs (Fig. 5).

Across the PMZ, the $\mathrm{L}_{2}$ lineation is preferentially E-W trending with a shallow to moderate plunge (Figs. 3C, 3D and 3E). Within the HPB, both in the top of the domes where the foliation is flat-lying, or along the steeply dipping foliation in the domes flanks, N-S striking subvertical melt-filled veins perpendicular to the maximum flattening plane, represented by the $\mathrm{S}_{2}$ foliation, argue for vertical shortening and E-W horizontal stretching. Thus, at the regional scale, orientation of the dilational sites is consistent with layer-parallel syn-anatectic stretching.

Folded nebulitic diatexites that suggest turbulent flow are not widespread and mainly located in the inner part of the HPB, in the core of the diatexite domes (Fig. 4C). More commonly, four types of fold can be distinguished owing to their geometry and their distribution pattern within the large-scale domes:

(i) In the top of the domes, $\mathrm{cm}$ to $\mathrm{m}$-scale tight folds with horizontal axial-planes resemble ptgymatitic folds (Fig. 4D).

(ii) Meter-scale upright folds with vertical axial plane that are preponderant along the E-W trending synformal keel that surrounds the domes, some larger 100-500 m-scale upright folds might be inferred from $\mathrm{S}_{2}$ orientation changes.

(iii) Along dome limbs, where $\mathrm{S}_{2}$ is moderately to steeply dipping, $\mathrm{cm}$ - to $\mathrm{m}$-scale recumbent folds verging away from the dome culmination are observed in diatexite. 
(iv) Intrafolial folds are the commonest ones that range in size from ten centimetres to few meters with axes parallel the $\mathrm{L}_{2}$ stretching direction (Fig. 4E).

Within diatexites, the progressive isoclinal folding of melanocratic layers accounts for transposition of an earlier disrupted compositional migmatitic $S_{2}$ foliation to a new one here denoted as $\mathrm{S}_{2 \mathrm{n}}$ (Figs. 4D and 4E). Such a transposition is frequently observed in the central and upper parts of the domes where the migmatitic foliation is flat lying to moderately dipping. In some outcrops, Dirks et al. (1997) recognized at least six overprinting foliationforming and folding events. At the whole HPB scale, transposition is mainly observed in the upper part of the Middle Diatexite where steeply dipping $\mathrm{S}_{2}$ is progressively changed in an horizontal one (Fig. 8). In addition, some high strained domains concentrated as highly stromatitic migmatites occur along vertical or steeply dipping foliation that delimitate dome in the Middle Diatexite (Fig. 4F).

\section{[ Figure 5 ]}

\section{[ Figure 6]}

\section{[ Figure 7 ]}

[ Figure 8 ]

\subsubsection{Westward non-coaxial regime}

In the western part of the HPB, the domal architecture turns gradually to a flat-lying structure defined by a relatively constant $\mathrm{S}_{2}$ foliation that preferentially dips westward (Figs. 3A and 3C). The D2 finite strain is heterogeneous with high strain domains concentrated along cm- to dm-scale shear zones where in-source leucosome or leucocratic vein commonly occur. The $\mathrm{L}_{2}$ lineation conspicuously plunges W or SW (Figs. 3C, 5 and 6). Kinematic 
indicators attest for a top-to-the $\mathrm{W}$ and $\mathrm{SW}$ normal shearing. This kinematic record is in agreement with previous work (Zhang et al., 1994; Dirks et al., 1997).

\subsubsection{Sinistral strike-slip shearing}

In the westernmost edge of the $\mathrm{HPB}, \mathrm{S}_{1-2}$ is steeply dipping with a $\mathrm{L}_{2}$ lineation that plunges weakly to moderately toward the southwest along which a sinistral strike-like movement with a normal component is observed (Figs. 3A and 3C). This sinistral strike-slip shearing is transitional in space with the westward one. A sinistral strike slip deformation is also observed in the northeastern edge of the PMZ, along the Longhua shear zone, north Chengde Massif, whereas few kinematic indicators attest for syn-anatectic dextral shearing along the hangingwall of the DCSZ, in Damiao village area (Fig. 3A).

\subsubsection{Northward verging syn-anatectic folding in the Hengshan Massif}

In the Hengshan Massif (southern PMZ), the $\mathrm{S}_{1-2}$ foliation is folded by open to tight, north verging, recumbent folds. Leucosomes concentrate in shear bands developed along the limbs and axial surfaces of the folds that constitute dilatants sites where melt preferentially migrate into. This fold axial plane is considered as a $S_{2 n}$ since the $S_{1-2}$ is folded. This synanatectic north verging folding is mainly observed south of the Zhujiafang Shear Zone, outside of the HPB (Fig. 9A).

[ Figure 9]

\section{3. $D_{3}$ Deformation stage}


The D3 deformation stage developed under subsolidus conditions. The E-W trending flow is also recognized in a subsolidus state during $\mathrm{D}_{3}$. In the central part of the HPB, $\mathrm{S}_{3}$ is flat lying and parallel to $\mathrm{S}_{2}$. Along the $\mathrm{L}_{3}$ mineral lineation, symmetric pressure shadows or porphyroclast systems argue for a coaxial regime (Fig. 9B). In some outcrops, a symmetric $\mathrm{D}_{3}$ boudinage (Fig. 9C) is also in agreement with a $\mathrm{D}_{3}$ coaxial flow, even if sometimes, a synanatectic $D_{2}$ fabric is still preserved within the lenses. In the western part of the HPB, $D_{3}$ shows a SW to W directed shearing that appears as parallel to the $\mathrm{D}_{2}$ strain.

The most prominent manifestation of $\mathrm{D}_{3}$ is the Datong-Chengde Shear Zone (DCSZ) that appears as a km-scale ductile normal shear zone (Figs. 3A and 3F). In its eastern part, the shear zone separates into a northern branch, the Longhua shear zone (LSZ) and a southern branch, the Damiao shear zone (DSZ; Fig. 3). S3 is a NW to N dipping mylonitic foliation that contains a NW plunging $\mathrm{L}_{3}$ stretching lineation (Figs. 10A, 10B and 10C). East of Chengde, between Sangou and Wutache, the S3 mylonitic foliation becomes near horizontal. Kinematic indicators show a top-to the NW displacement (Figs. 10D and 10E). Thus, in its present geometry, the DCSZ has a normal plus left-lateral kinematics. The sinistral strike-slip component is more pronounced in the western part of the DCSZ (Figs. 3 and 7).

The $\mathrm{D}_{3}$ mylonitic fabric developed at the granulite/amphibolite facies transition as evidenced by destabilisation of Opx porphyroblasts dynamically recristallized in an assemblage of orthopyroxene + amphibole + plagioclase (Fig. 10D). It is noteworthy that the DCSZ mainly developed in the footwall of the Middle Diatexite of the HPB. Along the eastern part of the DCSZ, some segments may have been reactivated during Paleozoic as expressed by the brittle-ductile steeply dipping Shangyi-Chicheng Fault (Hu et al., 2003).

\section{4. $D_{4}$ Deformation stage: the late Zhujiafang strike-slip shearing}


In the northern part of the Hengshan massif, the flat-lying to SW-dipping $\mathrm{S}_{2}$ is continuously deflected into an E-W trending steeply dipping orientation as approaching the Zhujiafang Shear Zone (ZSZ). The ZSZ is characterized by a subvertical to southward steeply dipping $\left(>70^{\circ}\right)$ mylonitic to ultramylonitic foliation that holds a horizontal to shallowly plunging stretching lineation along which a sinistral kinematics is observed (Trap et al., 2007; Wang, 2010). However, dextral component has been reported in the vicinity of the Zhujiafang shear zone (Kröner et al., 2006). Along the strike-slip shear zone, but out of the high-strain domain, a down-dip to highly plunging lineation, with the southern side moving downward, accounts for an early vertical movement (Trap et al., 2007).

[ Figure 10 ]

\section{Review of P-T paths and radiochronological data}

\subsection{P-T evolution of the HP rocks}

The commonest relics of HP rocks encountered in the Chengde Massif, Xuanhua Massif and Datong-Huai'an-Northern Hengshan area (Fig. 1) are retrograded eclogites and highpressure granulites. These rocks crop out as $10 \mathrm{~cm}$ - to $10 \mathrm{~m}$ scale boudins or flat sheets within amphibolite and granulite facies diatexites (Figs. 2A and 2B; Zhai et al., 1992; Zhao et al., 2000, 2001a; Guo et al., 2002; O'Brien et al., 2005; Zhang et al., 2006). The protoliths of the mafic granulites are magmatic rocks of doleritic and gabbroic composition interpreted as mafic dykes intruding a TTG gneissic sequence also known in the literature as the Grey Gneiss or Huai'an gneiss (Zhang et al., 1994; Guo et al., 2005; Kröner et al., 2005b; O’Brien 
et al., 2005). The occurrence of felsic granulites and metapelites indicates that the entire continental crust, i.e. the TTG basement gneiss, sedimentary cover and the mafic intrusions experienced the HP eclogitic and granulitic metamorphism during the early stages of the Trans-North China Orogeny.

The HP granulites of the Hengshan, North Datong, Huai'an, and Chengde massifs experienced a rather similar evolution (Fig. 11). The reconstructed P-T paths obtained for the high-pressure mafic granulites of the HPB are characterized by a clockwise evolution with a near-isothermal decompression followed by a final cooling (Fig. 11). Peak assemblages $\left(\mathrm{M}_{1}\right)$ are defined by a granultie facies garnet + clinopyroxene \pm quartz association and sometimes by an eclogite facies mineral assemblage of garnet + quartz + omphacite pseudomorphs (Zhao et al., 2001a; Zhang et al., 2006). The P-T path is then defined by medium-pressure granulite facies garnet + plagioclase + clinopyroxene + orthopyroxene \pm quartz assemblage $\left(\mathrm{M}_{2}\right)$ and a low-pressure granulite facies orthopyroxene \pm clinopyroxene + plagioclase \pm quartz assemblage $\left(\mathrm{M}_{3}\right)$. The end of the P-T path is defined by an amphibolite facies hornblende + plagioclase assemblage $\left(\mathrm{M}_{4}\right) . \mathrm{M} 1$ took place at $800-850{ }^{\circ} \mathrm{C} / 14-16 \mathrm{kbar}, \mathrm{M} 2$ and $\mathrm{M} 3$ occurred for $\mathrm{T} / \mathrm{P}$ conditions of $800-825^{\circ} \mathrm{C} / 10 \mathrm{kbar}$ and $800^{\circ} \mathrm{C} / 7-8 \mathrm{kbar}$, respectively. Thermo-barometric conditions of $650^{\circ} \mathrm{C} / 5 \mathrm{kbar}$ were estimated for M4 (Table 1; Fig 11; Zhai et al., 1992; Liu et al., 1993; Zhang et al., 1994; Zhao et al., 2000, 2001a; Guo et al., 2002, 2005; O’Brien et al., 2005; Zhang et al., 2006)

\section{[ Table 1 ]}

[ Figure 11 ]

\subsection{Radiochronological dataset}


Figure 12 and Table 2 summarize most of the available high-T radiochronological ages obtained for rocks within the HPB and its close surrounding units. This synthesis shows that the tectonic-metamorphic evolution of the TNCO can be subdivided into five periods, namely (1) 2550-2450 Ma, (2) 2300-1900 Ma, (3) 1880 Ma, (4) 1850 Ma (5) 1840-1800 Ma.

5.2.1. The 2550-2450 Ma period: Archean protoliths

A first pool of about twenty ages that fall into the range $2450-2550 \mathrm{Ma}$ is recorded in the HPB rocks (Table 2; Fig. 2). Most of the available ages recorded within the Trans-North China Orogen range between 2550 and 2450 Ma (e.g. Zhao et al. 2002, 2005, 2006; Guo et al., 2005; Kröner et al., 2005a-b; Wilde et al., 2005;). All the recent geochronological investigations using CL imaging and SHRIMP U-Pb zircon dating revealed that the $\sim 2500$ Ma ages represent protoliths ages obtained on inherited grains or core of grains (Kröner et al., 2005a-b; Wilde et al., 2005; Zhao et al., 2005). Correspondingly, within the HPB, the 2550$2450 \mathrm{Ma}$ ages may represent the timing of formation of the Archean-Paleoproterozoic magmatic protolith.

5.2.2. The 2300-1900 Ma period: Thermal and magmatic event

The oldest evidence for this event are a fine grained orthogneiss, a granite-gneiss and a trondhjemitic gneiss dated at $2358.7 \pm 0.5,2331 \pm 36,2329.7 \pm 0.6 \mathrm{Ma}$, respectively (Table 2; Fig. 12; Kröner et al., 2005b). Three felsic granitoids, one pegmatite and one anatectic granite have also been reported by Kröner et al. (2005b) at $2248.5 \pm 0.5 \mathrm{Ma}$ and $2113 \pm 8 \mathrm{Ma}$, respectively. One gabbroic rock from a metatexite of the OVU, south of the HPB, yielded a 
SHRIMP U-Pb age at $2193 \pm 15 \mathrm{Ma}$. Within the Huai' an massif, some ages around $2100 \mathrm{Ma}$ are also reported from Al-rich metasediments and some granitoids such as the Dongjiagou gneissic granite dated at $2036 \pm 19$ Ma (G.C. Zhao et al., 2008).

Similar 2.3-2.1 Ga ages were reported in the different TNCO massifs, in particular those obtained from plutonic and volcanic rocks in the Hengshan, Wutaishan and Fuping Massifs that argue for a tectono-thermal event around 2.1 Ga (Wilde et al. 1998, 2005; Zhao et al. 2002, Trap et al., 2008). However, the significance of this event in the tectonic evolution of the NCC still remains difficult to settle. The 2.3-2.1 Ga magmatism and volcanism might correspond to the formation of a marginal back-arc basin coeval with the development of the OVU (Faure et al., 2007, Z.H. Wang et al., 2010).

In the southern part of the HPB, two sets of magmatic zircons from two mafic highpressure granulites yielded mean ${ }^{207} \mathrm{~Pb} /{ }^{206} \mathrm{~Pb}$ ages of $1915 \pm 4 \mathrm{Ma}$ and $1914 \pm 2 \mathrm{Ma}$, respectively, interpreted as reflecting the time of emplacement of the gabbroic dyke precursors (Kröner et al., 2006). Due to the scarcity of such ages within the Trans-North China Belt, they are difficult to interpret in term of a tectono-metamorphic event. Nevertheless, the $\sim 1915 \mathrm{Ma}$ ages reported in two metapelites of the southwestern located Lüliang Massif represents a thermal or tectonic-metamorphic event older than the main regional metamorphism dated at $\sim 1880 \mathrm{Ma}$ (Trap et al., 2009b).

5.2.3. The $1880 \pm 10$ Ma period : time of peak metamorphism and crustal thickening

SHRIMP U-Pb ages of metamorphic zircons of $1881 \pm 8 \mathrm{Ma}$ and a mean evaporation $207 \mathrm{~Pb} / 206 \mathrm{~Pb}$ age of $1881.3 \pm 0.4 \mathrm{Ma}$ have been reported in the Hengshan migmatites (Table 1; Kröner et al., 2005a, 2006). Along the Zujiafang Shear Zone, a chemical U-Th-Pb monazite age from a kyanite-bearing metapelite yield a 1883 \pm 11 Ma age (Faure et al., 2007). Trap et al. 
(2007) interpreted the concordant $\mathrm{U}-\mathrm{Th}-\mathrm{Pb}$ monazite ages of $1887 \pm 4 \mathrm{Ma}, 1886 \pm 5 \mathrm{Ma}$ and $1884 \pm 11$ Ma from three metapelites located in the southern adjacent OVU unit as the age of the prograde amphibolite facies metamorphism coeval with nappe-stacking. In the Xuanhua Massif, Guo et al. (2005) obtained a zircon SHRIMP U-Pb age at $1872 \pm 16$ from the highpressure granulites. We interpret the 1870-1890 Ma period as the time of peak metamorphism coeval with nappe-stacking and crustal thickening during D1 event. In addition, the age of $1872 \pm 17$ recorded in a migmatitic leucosome of granitic composition (Kröner et al., 2005b) argues for the onset of partial-melting in response to crustal thickening, in agreement with Zhang et al. (1994) that postulated that melt was present at peak-assemblage conditions during the 1870-90 Ma period.

\section{[ Table 2 ]}

5.2.4. The $1850+-10$ Ma period: time of widespread crustal melting

Zircon conventional $\mathrm{U}-\mathrm{Pb}$ multigrain and SHRIMP U-Pb datings within the HP granulites yield pooled ages around $1850 \mathrm{Ma}$ (Table 2; Fig. 12; Zhao et al. 2002, 2005, 2006; Guo et al., 2005; Kröner et al., 2005a-b; Wilde et al., 2005; Wan et al., 2006; Faure et al., 2007; Wang et al., 2010a). In the Hengshan Massif, Kröner et al. (2005b) obtained metamorphic zircon $\mathrm{U}-\mathrm{Pb}$ ages of $1848 \pm 51850 \pm 3,1867 \pm 23,1859.7 \pm 0.5 \mathrm{Ma}$ from the high-grade granitoid gneisses and high-pressure mafic granulites. An ICP-MS U-Pb age at $1850 \pm 5 \mathrm{Ma}$ from metamorphic zircons rims of an anatectic leucosome has been interpreted to date partial-melting (Faure et al., 2007). In the Datong-Huai'an area, SHRIMP U-Pb dating of magmatic zircon from an anatectic charnockite and a granite (Dapinggou pluton), yield ages of $1849 \pm 9.8 \mathrm{Ma}$ and $1850 \pm 17 \mathrm{Ma}$, respectively (Zhao et al., 2008). Furthermore, the 
metamorphic zircons from TTG gneisses, Paleoproterozoic granitoids and khondalitic rocks yield similar concordant ${ }^{207} \mathrm{~Pb} /{ }^{206} \mathrm{~Pb}$ ages around $1850 \mathrm{Ma}$, coeval with the emplacement of the Huai'an anatectic charnockite and Dapinggou syn-collisional granite (Zhao et al., 2008). Therefore we interpret the numerous 1850-1860 Ma ages as the date of the period corresponding to the peak of crustal melting and related anatectic plutonism. This is in agreement with Wang et al. (2010a) that compiled metamorphic zircon ages for high-grade metamorphic rocks from the whole TNCO and revealed three age peaks at $1876 \pm 6 \mathrm{Ma}, 1849$ $\pm 2 \mathrm{Ma}$ and $1814 \pm 4 \mathrm{Ma}$. These authors poposed that $1845 \pm 7 \mathrm{Ma}$ is the best estimate for the timing of the HP metamorphism in the Huai'an Massif. In the light of the compilation we rather suggest that the $1845 \mathrm{Ma}$ age corresponds to the age of peak partial-melting and magmatism that post-date the peak pressure clearly settled at ca $1880 \mathrm{Ma}$.

\subsubsection{The $<1850$ Ma ages}

A set of magmatic ages around $1820 \pm 20 \mathrm{Ma}$ is recorded in a charnockite pluton and some granulites blocks (Table 2; Fig.12). Rimmed zircons within a migmatitic leucosome recorded a magmatic core at $1846 \pm 21 \mathrm{Ma}$ and a metamorphic rim at $1819 \pm 13 \mathrm{Ma}$ (Wang et al., 2010a). The $1820 \pm 20$ Ma ages might reflect a thermal metamorphism due to a latemagmatic pulse within the partially molten HPB. Finally, the latest ages of $1806 \pm 15$ and $1803 \pm 9$ Ma (Guo et al., 2005; Wang et al., 2010a) are similar to magmatic ages of unstrained post-tectonic granites that intrude the whole TNCO (e.g. Geng et al., 2000). Therefore in the $\mathrm{TNCO}$, the crust may have been partially molten during over $>50 \mathrm{Ma}$ as bracketed by the $1872 \pm 17$ and $1819 \pm 13 \mathrm{U}-\mathrm{Pb}$ ages recorded for two migmatitic leucosomes (Table 2; Kröner et al., 2005; Wang et al., 2010a). 
[ Figure 12 ]

\section{Discussion}

\subsection{Flow and exhumation of the TNCO thickened crust}

Four main tectono-metamorphic events are recorded in the HPB and PMZ that successively accounted for thickening, ductile flow and exhumation of the deeply buried orogenic crust. Within the HPB and surrounding units, the early $\mathrm{D}_{1}$ event is defined by a locally preserved NW-SE trending lineation with a top-to-the SE sense of shear. This structural pattern is recognized all over the TNCO and is related to the nappe-stacking and crustal thickening during building of the orogenic wedge (Faure et al., 2007; Trap et al., 2007, 2008, 2009). This conclusion is in agreement with Dirks et al. (1997) that suggested that a NW-SE trending mineral lineation marked by sillimanite inclusions within garnet could represent the early prograde event responsible for the interleaving of metasedimentary rocks and TTG gneiss of the HPB during burial and crustal thickening. The achievement of crustal thickening might have occurred around $1880 \pm 10 \mathrm{Ma}$ that dates the peak $\mathrm{M}_{1}$.

During the D2 event, the SW-NE to E-W trending coaxial flow and doming that developed in the core of the HPB is interpreted to result from interplay between diapirism and SE-NW to N-S shortening, during the eastward extrusion of the deep crust. Diapirism is related to uprising of low density partially-molten and magmatic rocks (diatexites) and is responsible for transposition of the vertical foliation toward a horizontal one in the upper part of the HPB. The N-S shortening is also documented by north-verging folding in the southern and upper part of the partially molten zone, in the Hengshan massif. This north-verging folding occurred in the inner part of the orogenic wedge during ongoing compression whereas 
the foreland domain suffered south-verging folding (Faure et al., 2007; Trap et al., 2007). As a consequence, the Hengshan-Wutai domain is structured as a fan-type wedge (Fig. 8; Trap et al., 2009b; Zhang et al., 2007, 2009). In the deeper part of the orogenic wedge, and together with the general E-W trending lateral flow, the top-to-the $\mathrm{W}$ - and top-to-the SW shearing observed in the western edge of the HPB suggests an eastward extrusion of the deep crust. The dominant sinistral strike-slip shearing observed along the northwestern and northern limit of the PMZ is also interpreted as the expression of this general eastward lateral flow of the PMZ. The flow direction turns from NNE-SSW in the southwestern part of the HPB to E-W in the middle and eastern parts, i.e. it parallels the Trans-North-China Suture.

The D2 event occurs under syn-anatectic conditions, during the retrograde metamorphic evolution that postdates $M_{1}$, i.e. the part of the P-T path between $M_{1}$ and $M_{3}$ that follow the melt-enhanced geotherm (Fig.11). This portion of the retrogressive P-T path argues for decompression from $\sim 14 \mathrm{kbar}$ to $\sim 8 \mathrm{kbar}$, which corresponds to nearly $20 \mathrm{~km}$ of unroofing (Fig. 11). As shown above in section 4 , the $\mathrm{D}_{2}$ flow is mainly horizontal. Nevertheless, even a weak plunge of the $\mathrm{L}_{2}$ lineation will be sufficient to accommodate the amount of exhumation inferred from thermobarometry. For instance, a $100 \mathrm{~km}$ E-W striking flow along a $10^{\circ}$ (respectively $15^{\circ}$ ) westward plunging flow line will produce a vertical displacement of $17 \mathrm{~km}$ (respectively $26 \mathrm{~km}$ ).

The D3 event developed under subsolidus conditions after the $\mathrm{M}_{3}$ metamorphism. From $\mathrm{M}_{3}$ to $\mathrm{M}_{4}$, the P-T path does no more follow the melt-enhanced geotherm and enters the stability field of amphibole (Figs. $10 \mathrm{G}$ and 11 ). The $\mathrm{D}_{3}$ event is also characterized by an E-W trending flow and the motion along the DCSZ. All along the DCSZ, a top-to-the NW normal shearing with a sinistral strike slip component has been documented (cf. section 4). The sense of shear on the channel detachment is top-to-the-WNW on its western part and top-to-the NNW along its northern part. The activity of this strike-slip shear zone may account for the 
late stage of the exhumation and eastward tectonic escape of the HPB. The diatexite/metatexite transition probably played the role of a rheological boundary along which the $\mathrm{D}_{3}$ deformation concentrated.

\subsection{Critical parameters for the HPB exhumation: orocline geometry and partial melting}

Ductile flow and exhumation of the deep parts of the thickened crust are mainly controlled by the interplay between boundary forces and gravity related forces (i.e. buoyancy forces). Along an orogenic belt, boundary forces mostly change as a function of the belt geometry due to the shape of crustal blocks involved in the collision. Gravity related forces driven by buoyancy change in response to lateral variations of crustal thickness (Royden, 1996; Rey et al., 2001). Modifications of rock density due to metamorphic reactions, partial-

melting and magma displacement are the main parameters that control the buoyancy force (Vanderhaeghe, 2009). Hereafter, we discuss the concurrent effect of oroclinal bending and partial-melting to produce the finite architecture of the High Pressure Belt.

\subsubsection{TNCO geometry and boundary forces balance}

The PMZ lies in a specific location along the Trans-North China Suture from the core of the orocline and to the eastern part of the belt. Along the N-S trending branch of the TransNorth China Orogen, where the crustal nappes are rooted in the TNCS (Faure et al., 2007; Trap et al., 2009b), the tectonic regime is compressional, whereas along the E-W part of the belt, a strike-slip regime is predominant. One might consider that boundary forces are greater in the compressional domain than in the strike-slip dominant one. Therefore, the ongoing compression of the thickening orogenic root is responsible for forceful lateral eastward 
extrusion-exhumation of the deep rocks softened by partial-melting. The transpressional regime progressively turns into a transtensional one concentrated along the DCSZ.

\subsubsection{Partial melting}

Onset of partial-melting and formation of metatexites at peak metamorphism is responsible for a first strength drop of the buried continental crust. This rheological softening may have enhanced the lateral flow of the thickened crust which is also controlled by the bulk architecture of the orogen. The radiometric ages recorded in the HPB show that the deep crust was partially molten over a $50 \mathrm{Ma}$ lasting period.

During this time-scale, the partially molten crust evolved. Firstly the melt fraction increased due to decompression related reactions. Secondly, the melt migrated and was collected in the diatexite level, such as describe by Vanderhahge (2009) in several orogenic belts. This led to the subdivision of the PMZ with a core made of diatexites mantled by metatexites, the former forming a high volume, low density body complete around 1850 Ma. Within this partially molten crust, the HPB was delimited by two main discontinuities, the DCSZ and the ZSZ that both developed along the diatexite-metatexite boundary. This subdivision is responsible for a second strength drop with deformation accommodated along the diatexite/metatexite transition. The transtensional regime observed along the DCSZ has been triggered by the gravitational-thermal instability created by the migration and accumulation of melt within the crust. Similarly, the ZSZ is located along the metatexitediatexite boundary along which strain localized during deformation coeval with crustal melting and continues at sub-solidus state. The ZSZ certainly participated to the unroofing of the HPB. Indeed, a vertical offset of about $15 \mathrm{~km}$ between both sides of the shear zone has 
been documented (O'Brien et al., 2005). However, the D4 sinistral strike slip shearing completely erased any previous $\mathrm{D}_{2}$ fabric evidence along this shear zone.

In several HP rocks occurrences worldwide, the decompressional steep part of the PT-t paths commonly argues for rapid upward movement of the HP units that prevents thermal reequilibrium (e.g. Platt, 1993; Selverstone et al., 1992; Štípská and Schulmann, 1995). Following this assumption, Guo et al (2002) considered that the geometry of the ITD part of the P-T-path recorded in the HPB suggests that the rate of exhumation was clearly high at the beginning of unroofing. However, the main part of the adiabatic decompression for the HPB rocks occured for high-temperature suprasolidus conditions, and follows the melt-enhanced geotherm (Fig. 11; Depine et al., 2008). The evolution followed by the high-pressure rocks then remained isothermal during unroofing because of thermal buffering by melting reactions (Depine et al., 2008). Thus, an appraisal of the exhumation rates can hardly be derived from the shape of the P-T path even in the case of the steep decompressional path recorded in the HPB. Further studies focused on the construction of precise P-T-t-deformation paths are needed to estimate the exhumation rate of the HPB.

\section{Conclusion}

The HP rocks of the TNCO are exhumed through lateral flow of a partially molten channel and subsequent detachment shearing. This exhumation history was controlled by the bulk architecture of the TNCO orocline and by intense partial-melting of the thickened crust. Partial-melting is critical since it triggers strength drop and lateral flow and buffers temperature allowing the preservation of a high thermal regime and weakness of the crust for a long time period $(\sim 50 \mathrm{Ma})$. These rheological conditions may have accommodated ductile, along-strike flow over more than $100 \mathrm{~km}$ that corresponds to ca. $20 \mathrm{~km}$ in vertical component 
of unroofing. Therefore the onset of partial-melting in the deep crust is the critical threshold in the collision orogeny, from which compressional forces are balanced by orogen-parallel lateral escape. During the ongoing flow of the partially molten crust, melt migration yield to the development of diatexite unit and two rheological discontinuities at the metatexite/diatexite boundaries. These two limits are the preferred site along which subsolidus ductile deformation concentrate as shown by the Chengde-Datong Shear Zone that is responsible for the late stage of exhumation of the HP rocks.

\section{Acknowledgement}

The field work for this research was financially supported by a National Science Foundation of China grant no. 40472116. We thank M. Santosh, J. Zhang and an anonymous reviewer that helped us to clarify some key points and improve the manuscript.

\section{References}

Beaumont, C.J., Jamieson, R.A., Nguyen, M.H., Lee, B., 2001. Himalayan tectonics explained by extrusion of a low-viscosity crustal channel coupled to focused surface denudation. Nature 414, 738-742.

Beaumont, C.J., Jamieson, R.A., Nguyen, M.H., Medvedev, S., 2004. Crustal channel flows: 1. Numerical models with applications to the tectonics of the Himalayan-Tibetan orogen: Journal of Geophysical Research 109, B06406, doi:10.1029/2003JB002809.

Beaumont, C.J., Nguyen, M.H., Jamieson, R.A., Ellis, S., 2006. Crustal flow modes in large hot orogens. In: Law, R.D., Searle, M.P., Godin, L. (Eds.), Channel flow, ductile extrusion 
and exhumation in continental collision zones. Geological Society of London Special Publication 268, 91-145.

Condie, K.C., Boryta, M.D., Liu, J., 1992. The origin of khondalites: geochemical evidence from the Archean to early Proterozoic granulite belt in the North China Craton. Precambrian Research 59, 207-223.

Davis, G. A., Zheng, Y. D., Wang, C., 2005. Mesozoic tectonic evolution of the Yanshan fold and thrust belt, with emphasis on Hebei and Liaoning provinces, northern China. Memoir of the Geological Society of America 194, 171-197.

Depine, G.V., Andronicos, C.L., Phipps-Morgan, J., 2008. Near-isothermal conditions in the middle and lower crust induced by melt migration. Nature $452,80-83$.

Dirks, P.H.G.M., Zhang, J.S., Passchier, W.C., 1997. Exhumation of high-pressure granulites and the role of lower crustal advection in the North China Craton near Datong. Journal of Structural Geology 19, 1343-1358.

Faure, M., Trap, P., Lin, W., Monie, P., Bruguier, O., 2007. Polyorogenic evolution of the Paleoproterozoic Trans-North China Belt, new insights from the Lüliangshan-HengshanWutaishan and Fuping massifs. Episodes 30, 1-12.

Geng, Y.S., Wan, Y.S., Shen, Q.H., Li, H.M., Zhang, R.X., 2000. Chronological framework of the early Precambrian important events in the Lüliang area, Shanxi Province. Acta Geologica Sinica 74, 216-223 (in Chinese with English abstract).

Gervais, F., Brown, R.L., 2011. Testing modes of exhumation in collisional orogens: Synconvergent channel flow in the southeastern Canadian Cordillera. Lithosphere 3, 5575.

Grujic, D., 2006. Channel flow and continental collision tectonics: An overview. In: Law, R.D., Searle, M.P., Godin, L. (Eds.), Channel flow, Ductile Extrusion and Exhumation in 
Continental Collision Zones: Geological Society of London Special Publication 268, 2537.

Guo, J.H., Zhai, M.G., Zhang, Y.G., 1993. Early Precambrian Manjinggou high-pressure granulites melange belt on the southern edge of the Huai' an Complex, North China Craton: geological features, petrology and isotopic geochronology. Acta Petrologica Sinica 9, 329341.

Guo, J.H., O’Brien, P.J., Zhai, M.G., 2002. High-pressure granulites in the Sangan area, North China Craton: metamorphic evolution, P-T paths and geotectonic significance. Journal of Metamorphic Geology 20, 741-756.

Guo, J.H., Sun, M., Zhai, M.G., 2005. Sm-Nd and SHRIMP U- Pb zircon geochronology of high-pressure granulites in the Sanggan area, North China Craton: timing of Paleoproterozoic continental collision. In: Wilde, S.A., Zhao, G.C. (Eds.), Late Archean to Paleoproterozoic Evolution of the North China Craton. Journal of Asian Earth Science 24, $529-542$.

Hu, L., Song, H.L., Yan, D.P., Hu, D.G., 2003. The ${ }^{40} \mathrm{Ar} /{ }^{39} \mathrm{Ar}$ geochronology constraint and geological significance of mylonites in Shangyi-Chicheng fault belt on the north of the North China Craton. Science in China (Series D) 46, 1134-1141.

Jamieson, R.A., Beaumont, C.J., Medvedev, S., Nguyen, M.H., 2004. Crustal channel flows: 2. Numerical models with implications for metamorphism in the Himalayan-Tibetan orogen: Journal of Geophysical Research 109, B06407, doi:10.1029/2003JB002811.

Jamieson, R.A., Beaumont, C.J., Nguyen, M.H., Grujic, D., 2006. Provenance of the Greater Himalayan Sequence and associated rocks; predictions of channel flow models. In: Law, R.D., Searle, M.P., Godin, L. (Eds.), Channel Flow, Ductile Extrusion and Exhumation in Continental Collision Zones: Geological Society of London Special Publication 268, 165182. 
Kröner, A., Wilde, S.A., Li, J.H., Wang, K.Y., 2005a. Age and evolution of a late Archean to Paleoproterozoic upper to lower crustal section in the Wutaishan/Hengshan/Fuping terrain of northern China. Journal of Asian Earth Science 24, 577-595.

Kröner, A., Wilde, S.A., O'Brien, P.J., Li, J.H., Passchier, C.W., Walte, N.P., Liu, D.Y., 2005b. Field relationships, geochemistry, zircon ages and evolution of a late Archaean to Palaeoproterozoic lower crustal section in the Hengshan Terrain of northern China. Acta Geologica Sinica-English Version 79, 605-632.

Kröner, A.,Wilde, S.A., Zhao, G.C., O’Brien, P.J., Sun, M., Liu, D.Y., Wan, Y.S., Liu, S.W., Guo, J.H., 2006. Zircon geochronology and metamorphic evolution of mafic dykes in the Hengshan Complex of northern China: evidence for late Palaeoproterozoic extension and subsequent high-pressure metamorphism in the North China Craton. Precambrian Research $146,45-67$.

Kusky, T.M., Li, J.H., 2003. Paleoproterozoic tectonic evolution of the North China Craton. Journal of Asian Earth Science 22, 23-40.

Kusky, T.M., Li, J.H., Santosh, M., 2007. The Paleoproterozoic North Hebei Orogen: North China Craton's Collisional Suture with the Columbia Supercontinent. Gondwana Research $12,4-28$.

Li, J.H., Qian, X.L., Huang, X.N., Liu, S.W., 2000a. The tectonic framework of the basement of North China craton and its implication for the early Precambrian cratonization. Acta Petrologica Sinica 16, 1-10.

Li, J.H., Kröner, A., Qian, X.L., O’Brien, P., 2000b. The tectonic evolution of an early Precambrian high-pressure granulite belt in the North China craton. Acta Geologica Sinica $74,246-256$.

Li, J.H., Kusky, T.M., 2007. A late Archean foreland fold and thrust belt in the North China Craton: implications for early collisional tectonics. Gondwana Research 12, 47-66. 
Li, J.H., Qian, X.L., 1994. Late Archean continental cratonization: evidence from Hengshan metamorphic terrain, North China Craton. In: Geological Evolution of the Granulitic Belt in the North Part of North China. Publishing House of Sismology, Beijing, 234.

Li, S.Z., Zhao, G.C., 2007. SHRIMP U-Pb zircon geochronology of the Liaoji granitoids: constraints on the evolution of the Paleoproterozoic Jiao-Liao-Ji belt in the Eastern Block of the North China Craton. Precambrian Research 158, 1-16.

Li, J.H., Zhai, M.G., Li, Y.G., Zhan, Y.G., 1998. Discovery of Late Archean high-pressure granulites in Luanping-Chengde area, Northern Hebei Province: tectonic implications. Acta Petrologica Sinica 14, 34- 41.

Li, S.Z., Zhao, G.C., Wilde, S.A., Zhang, J., Sun, M., Zhang, G.W., Dai, L.M., 2010. Deformation history of the Hengshan-Wutai-Fuping Complexes: Implications for the evolution of the Trans-North China Orogen. Gondwana Research 18, 611-631.

Liu, F.L., 1995. Metamorphic mineral-fluid evolution and tectonic environments of the granulite facies terrane in the Huaian - Datong area. Ph.D. dissertation, Changchun University of Science and Technology, Changchun in Chinese with English Abstract.

Liu, S.W., Pan, P.M., Xie, Q.L., Zhang, J., Li, Q.G., 2004. Archean geodynamics in the Central Zone, North China Craton: Constraints from geochemistry of two contrasting series of granitoids in the Fuping and Wutai Complexes. Precambrian Research 130, 229249.

Liu, S.W., Zhao, G.C., Wilde, S.A., Shu, G.M., Sun, M., Li, Q.G., Tian, W., Zhang, J., 2006. $\mathrm{Th}-\mathrm{U}-\mathrm{Pb}$ monazite geochronology of the Lüliang and Wutai Complexes: constraints on the tectonothermal evolution of the Trans-North China Orogen. Precambrian Research $148,205-225$.

Liu, X.S., Jin, W., Li, S.X., Xu, X.C., 1993. Two types of Precambrian high-grade metamorphism, Inner Mongolia, China. Journal of Metamorphic Geology 11, 499 - 510. 
Mao, D.B., Zhong, C.T., Chen, Z.H., Lin, Y.X., Li, H.M., Hu, X.D., 1999. Isotopic ages and geological implications of high-pressure mafic granulites in the northern Chengde area, Hebei Province, China. Acta Petrologica Sinica 15, 524-534.

O’Brien, P.J., Röttzler, J., 2003. High pressure granulites: formation, recovery of peak conditions and implications for tectonics. Journal of Metamorphic Geology 21, 3-20.

O'Brien, P.J., Walte, N., Li, J.H., 2005. The petrology of two distinct granulite types in the Hengshan Mts, China, and tectonic implications. Journal of Asian Earth Science 24, 615627.

Platt, J., 1993. Exhumation of high pressure rocks: a review of concepts and processes. Terra Nova 5, 119-133.

Polat, A., Kusky, T., Li, J.H., Fryer, B., Kerrich, R., Patrick, K., 2005. Geochemistry of Neoarchean (ca. 2.55-2.50 Ga) volcanic and ophiolitic rocks in the Wutaishan greenstone belt, central orogenic belt, North China craton: implications for geodynamic setting and continental growth. Geological Society American Bulletin 117, 1387-1399.

Polat, A., Hersberg, C., Münker, C., Rodgers, R., Kusky, T., Li, J.H., Fryer, B., Delaney, J., 2006. Geochemical and petrological evidence for a suprasubduction zone origin of Neoarchean (ca. $2.5 \mathrm{Ga}$ ) peridotites, central orogenic belt, North China craton. Geological Society American Bulletin 118, 771-784.

Rey, P.F., Teyssier, C., Whitney, D.L., 2010. Limit of channel flow in orogenic plateaux. Lithosphere 2, 328-332.

Rey, P., Vanderhaeghe, O., Teyssier, C., 2001. Gravitational collapse of the continental crust: definition, regimes and modes. Tectonophysics 342, 435-449.

Royden, L., 1996. Coupling and decoupling of the crust and mantle in convergent orogens: implications for strain partitioning in the crust. Journal of Geophysical Research 101, 679705. 
Sanderson, D., Marchini, W., 1984. Transpression. Journal of Structural Geology 6, 449-458.

Santosh, M., Sajeev, K., Li, J.H., 2006. Extreme crustal metamorphism during Columbia supercontinent assembly: evidence from North China Craton. Gondwana Research 10, $256-266$.

Santosh, M., Tsunogae, T., Li, J.H., Liu, S.J., 2007a. Discovery of sapphirine-bearing Mg-Al granulites in the North China Craton: implication for Paleoproterozoic ultrahightemperature metamorphism. Gondwana Research 159, 178-196.

Santosh, M., Wilde, S.A., Li, J.H., 2007b. Timing of Paleoproterozoic ultrahigh-temperature metamorphism in the North China Craton: evidence from SHRIMP U-Pb zircon geochronology. Precambrian Research 159, 178-196.

Santosh, M., Sajeev, K., Li, J.H., Liu, S.J., Itaya, T., 2009. Counterclockwise exhumation of a hot orogen: the Paleoproterozoic ultrahigh-temperature granulites in the North China Craton. Lithos 110, 140-152.

Santosh, M., 2010. Assembling North China Craton within the Columbia supercontinent: The role of double-sided subduction. Precambrian Research 178, 149-167.

Sawyer, E.W., 2008. Atlas of migmatites. The Canadian Mineralogist, Special Publication 9, NRC research Press, Ottawa, Ontario, Canada, 371 p.

SBGMR (Shanxi Bureau of Geology and Mineral Resources), 1989. Regional Geology of Shanxi Province, Geological Publishing House, Beijing, 780 p.

Selverstone, J., Wernicke, B.P., Aliverti. E.A., 1992. Intracontinental subduction and hinged unroofing along the Salmon River suture zone, west central Idaho. Tectonics 11, 124-144.

Štípská, P., Schulmann, K., 1995. Inverted metamorphic zonation in a basement- derived nappe sequence, eastern margin of the Bohemian Massif. Geological Journal 30, 385-413.

Thompson, A.B., Connolly, J.A.D., 1995. Melting of the continental-crust: some thermal and petrological constraints on anatexis in continental collision zones and other tectonic 
settings. Journal of Geophysical Research 100, 15565-15579.

Tian, Y.Q., 1991. Geology and Gold Mineralization of Wutai - Hengshan Greenstone Belt. Shanxi Science and Technology Press, Taiyuan.

Tian, Y.Q., Ma, Z.H., Yu, K.R., Liu, Z.H., Peng, Q.M., 1996. The early Precambrian geology of Wutai-Hengshan Mts., Shanxi, China. In: Field Trip Guide T315 30th International Geological Congress, Beijing, China. Geological Publishing House, Beijing, 52 pp.

Trap, P., Faure, M., Lin, W., Monié, P., 2007. Late Paleoproterozoic (1900-1800 Ma) nappestacking and polyphase deformation in the Hengshan-Wutaishan area: implications for the understanding of the Trans-North-China Belt, North China Craton. Precambrian Research $156,85-106$.

Trap, P., Faure, M., Lin, W., Bruguier, O., Monié, P., 2008. Contrasted tectonic styles for the Paleoproterozoic evolution of the North China Craton. Evidence for a $\sim 2.1$ Ga thermal and tectonic event in the Fuping Massif. Journal of Structural Geology 30, 1109-1125.

Trap, P., Faure, M., Lin, W., Monié, P., Meffre, S., Melleton, J., 2009a. The Zanhuang Massif, the second and eastern suture zone of the Paleoproterozoic Trans-North China Orogen. Precambrian Research 172, 80-98.

Trap, P., Faure, M., Lin, W., Monié, P., Meffre, S., 2009b. The Lüliang Massif: a key area for the understanding of the Palaeoproterozoic. In: Evans D., Reddy, S., Collins, A. (Eds.), Palaeoproterozoic Supercontinents and Global Evolution. Geological Society of London, Special Publication 323, 99-125.

Vanderhaeghe, O., Medvedev, S., Fullsack, P., Beaumont, C.J., Jamieson, R.A., 2003. Evolution of orogenic wedges and continental plateaux: Insights from crustal thermalmechanical models overlying subducting mantle lithosphere: Geophysical Journal International 153, 27-51. 
Vanderhaeghe, O., 2009. Migmatites, granites and orogeny: flow modes of partially-molten rocks and magmas associated with melt/solid segregation in orogenic belts. Tectonophysics 477, 119-134.

Wan, Y. S., Wilde, S. A., Liu, D. Y., Yang, C. X., Song, B., Yin, X. Y., 2006. Further evidence for $\sim 1.85 \mathrm{Ga}$ metamorphism in the Central Zone of the North China Craton: SHRIMP U-Pb dating of zircon from metamorphic rocks in the Lushan area, Henan Province. Gondwana Research 9, 189-197.

Wang, Z.H., 2009. Tectonic evolution of the Hengshan-Wutai-Fuping complexes and its implication for the Trans-North China Orogen. Precambrian Research 131, 323-343.

Wang, Z.H., 2010. Reply to the comment by Zhao et al. on: "Tectonic evolution of the Henghsan-Wutai-Fuping complexes and its implicaion for the Trans-North China Orogen" [ Precambrian Res. 170 (2009) 73-87]. Precambrian Research 176, 99-104.

Wang, R.M., Lai, X.Y., Dong, W.D., Ma, J., Tang, B., 1994. Some evidence for the Late Archean collisional belt in the western Hebei Province. In: Qian, X.L.,Wang, R. (Eds.), Geological Evolution of the Granulite Terrains in the Part of the North China Craton. Seismological Press, Beijing, 7-20.

Wang, K.Y., Li, J.L., Hao, J., Li, J.H., Zhou, S.P., 1996. The Wutaishan mountain belt within the Shanxi province, Northern China: a record of late Archean collision tectonics. Precambrian Research 78, 95-103.

Wang, J., Wu, Y.B, Gao, S., Peng, M., Liu, X.C., Zhao., L.S., Zhou, L., Hu, Z.C., Gong, H.J., Liu, Y.S., 2010. Zircon U-Pb and trace element data from rocks of the Huai'an Complex: New insights into the late Paleoproterozoic collision between the Eastern and Western Blocks of the North China Craton. Precambrian Research 178, 59-71.

Wang, Z.H, Wilde, S.A., Wan, J.L, 2010. Tectonic setting and significance of 2.3-2.1 Ga magmatic events in the Trans-North China Orogen: New constraints from the Yanmenguan 
mafic-ultramafic intrusion in the Hengshan-Wutai-Fuping Area. Precambrian Research $178,27-42$.

Wilde, S.A., Cawood, P.A., Wang, K.Y., Nemchin, A., 1998. SHRIMP U-Pb zircon dating of granites and gneisses in the Taihangshan-Wutaishan area: implications for the timing of crustal growth in the North China craton. Chinese Science Bulletin 43, 144-145.

Wilde, S.A., Zhao, G.C., 2005. Archean to Paleoproterozoic evolution of the North China Craton. Journal of Asian Earth Science 24, 519-522.

Wu, C.H., Zhong, C.T., 1998. Early Proterozoic SW-NE collision model for the central part of the North China Craton: implications for tectonic regime of the khondalite downward into lower crust in Jin-Meng highgrade region. Progress In Precambrian Research 21, 28 50 (in Chinese with English abstract).

Yin, C.Q., Zhao, G.C., Sun, M., Leung, W.H., 2007. Metamorphic evolution and tectonic implications of the Qianlishan-Zhuozishan Complex of the Palaeoproterozoic Khondalite Belt in the Western Block, North China Craton. Geochimica et Cosmochimica Acta 15, A1146.

Yin, C.Q., Zhao, G.C., Sun, M., Xia, X.P., Wei, C.J., Zhou, X.W., Leung, W.H., 2009. LAICPMS U-Pb zircon ages of the Qianlishan Complex: constrains on the evolution of the Khondalite Belt in the Western Block of the North China Craton. Precambrian Research $174,78-94$

Yin, C.Q., Zhao, G.C., Guo, J.H., Sun, M., Xia, X.P., Zhou, X.W., Liu, C.H., 2011. U-Pb and Hf isotopic study of zircons of the Helanshan Complex: Constrains on the evolution of the Khondalite Belt in the Western Block of the North China Craton. Lithos 122, 25-38.

Zhai, M.G., Guo, J.H., Yan, Y.H., 1992. Discovery and preliminary study of the Archean high-pressure granulites in the North China. Science in China 12B, 1325-1330. 
Zhai, M.G., Guo, J.H., Li, J.H., Yan, Y.H., Li, Y.G., Zhang, W.H., 1995. The discovery of Archaean retrograde eclogites in the North China craton. China Science Bulletin 40, 15901594.

Zhai, M.G., Bian, A.G., Zhao, T.P., 2000. The amalgamation of the supercontinent of North China Craton at the end of Neo-Archaean and its breakup during late Palaeoproterozoic and Mesoproterozoic. Science in China Series D 43, 219-232.

Zhang, J.S., Dirks, H.G.M., Passchier, C.W., 1994. Extensional collapse and uplift in a polymetamorphic granulite terrain in the Archean and Paleoproterozoic of north China. Precambrian Research 67, 37-57.

Zhang, J., Zhao, G.C., Sun, M., Wilde, S.A., Li, S.Z., Liu, S.W., 2006. High-pressure mafic granulites in the Trans-North China Orogen: Tectonic significance and age. Gondwana Research 9, 349-362.

Zhang, J., Zhao, G.C., Li, S.Z., Sun, M., Liu, S.W., Wilde, S.A., Kröner, A., Yin, C.Q., 2007. Deformation history of the Hengshan Complex: implications for the tectonic evolution of the Trans-North China Orogen. Journal of Structural Geology 29, 933-949.

Zhang, J., Zhao, G.C., Li, S.Z., Sun, M., Wilde, S.A., Liu, S.W., Yin, C.Q., 2009. Polyphase deformation of the Fuping Complex, Trans-North China Orogen: Structures, SHRIMP U$\mathrm{Pb}$ zircon ages and tectonic implications. Journal of Structural Geology 31, 177-193.

Zhao, G.C., Wilde, S.A., Cawood, P.A., Lu, L.Z., 1998. Thermal evolution of Archean basement rocks from the eastern part of the North China Craton and its bearing on tectonic setting. International Geological Review 40, 706-721.

Zhao, G.C., Cawood, P.A., Wilde, S.A., Lu, L.Z., 2000. Metamorphism of basement rocks in the Central Zone of the North China Craton: implications for Paleoproterozoic tectonic evolution. Precambrian Research 103, 55-88. 
Zhao, G.C., Cawood, P.A., Wilde, S.A., Lu, L.Z., 2001a. High-pressure granulites (retrograded eclogites) from the Hengshan Complex, North China Craton: petrology and Tectonic implications. Journal of Petrology 42, 1141- 1170.

Zhao, G.C., Wilde, S.A., Cawood, P.A., Sun, M., 2001b. Archean blocks and their boundaries in the North China Craton: lithological, geochemical, structural and P-T path constraints and tectonic evolution. Precambrian Research 107, 45-73.

Zhao, G.C., Wilde, S.A, Cawood, P.A., Sun, M., 2002. SHRIMP U-Pb zircon ages of the Fuping Complex: implications for accretion and assembly of the North China Craton. American Journal of Science 302, 191-226.

Zhao, G.C., Sun, M., Wilde, S.A., 2003. Major tectonic units of the North China Craton and their Paleoproterozoic assembly. Science in China Series D 46, 23-38.

Zhao, G.C., Sun, M., Wilde, S.A., Guo, J.H., 2004. Late Archean to Palaeoproterozoic evolution of the trans-North China Orogen: insights from synthesis of existing data from the Hengshan-Wutai-Fuping belt. In: Malpas, J., Fletcher, C.J.N., Ali, J.R., Aitchison, J.C. (Eds.), Aspects of the Tectonic Evolution of China. Geological Society of London Special Publication 226, 27-55.

Zhao, G.C., Sun, M., Wilde, S.A., Li, S.Z., 2005. Late Archean to Paleoproterozoic evolution of the North China Craton: key issues revisited. Precambrian Research 136, 177- 202.

Zhao, G.C., Sun, M., Wilde, Li, S.Z., Liu, S.W., Zhang, J., 2006. Composite nature of the North China Granulite-Facies Belt: Tectonothermal and geochronological constraints. Gondwana Research 9, 337-348.

Zhao, G.C., Wilde, S.A., Sun, M., Guo, J.H., Kröner, A., Li, S.Z., Li, X.P., Wu, C.M., 2008. SHRIMP U-Pb zircon geochronology of the Huaian Complex: constraints on Late Archean to Paleoproterozoic crustal accretion and collision of the Trans-North China Orogen. American Journal of Science 308, 270-303. 
Zhao, G.Z., Wilde, S.A., Guo, J.H., Cawood, P.A., Sun, M., Li, X.P., 2010. Single zircon grains record two Paleoproterozoic collisional events in the North China Craton. Precambrian Research 177, 266-276.

\section{Figure captions}

Figure 1. A: Paleoproterozoic-Archean massifs of the North China Craton (NCC) and location of the Trans-North China Orogen (TNCO). B: Lithotectonic map of the Trans-North China Orogen, with the three-fold subdivision of the NCC and two suture zones as described in Faure et al. (2007) and Trap et al. (2007, 2008, 2009a-b). First interpreted boundaries of the TNCO, from Zhao et al. (2000) are also represented in dashed line.

Figure 2. Photographs of some morphological types of migmatitic rocks within the PartiallyMolten Zone (PMZ). A: Mafic metatexites from the Lower Metatexite $\left(\mathrm{N} 40^{\circ} 51.942 / \mathrm{E} 115^{\circ} 38.334\right)$. Some peritectic garnet porphyroblasts are no more contoured by peritectic melt, and this weak amount of leucosome argues for melt loss. The rock suffered retrogradation in amphibolite facies. B: HP mafic granulite block within a diatexite from the Middle Diatexite $\left(\mathrm{N} 40^{\circ} 45.733 / \mathrm{E} 114^{\circ} 20.968\right)$. Insert: typical retrograde amphibole and plagioclase in kelyphites around garnet porphyroblasts. C: Diatexite from the Northern Hengshan Massif showing the magmatic fabric marked by alignement of schlieren $\left(\mathrm{N} 40^{\circ} 45.027 / \mathrm{E} 114^{\circ} 20.965\right)$. D: Schollen diatexite $\left(\mathrm{N} 40^{\circ} 40.126 / \mathrm{E} 116^{\circ} 40.298\right)$. E: Metatexite formed at the expense of an Al-rich metasediment (khondalite of the Upper Metatexite Unit $\left.\left(\mathrm{N} 40^{\circ} 14.445 / \mathrm{E} 113^{\circ} 17.739\right)\right)$. The rock contains a high melt fraction and shows some highstrain domains (e.g. right of the hammer). F: Patch metatexite with a very low melt fraction 
formed at the onset on melting (Outer Metatexite, North of CDSZ, $\left.\mathrm{N} 41^{\circ} 01.510 / \mathrm{E} 115^{\circ} 00.715\right)$.

Figure 3. Structural map and synoptic representation of $\mathrm{D}_{1}, \mathrm{D}_{2}, \mathrm{D}_{3}$ and $\mathrm{D}_{4}$ structural elements over the whole HPB and its surroundings units. Poles to foliation and lineations are plotted in the lower hemisphere of equal-area stereographic projections.

Figure 4. Photographs of some $\mathrm{D}_{2}$ structural elements within the partially-molten HPB rocks. A: Upper Metatexite located in the central part of the HPB showing a flat lying $\mathrm{S}_{2}$ foliation $\left(\mathrm{N} 40^{\circ} 22.992 / \mathrm{E} 114^{\circ} 28.92\right)$. Leucosome located inside inter-boudins partitions attests for synanatectic vertical shortening, E-W horizontal stretching and migration of anatectic melts from highly shortened foliation planes toward dilatants sites. B: Upper metatexite located along the northern limit of the HPB. $\mathrm{S}_{2}$ is E-W trending and vertical, and leucosome within interboudins partitions attests for syn-anatectic N-S horizontal shortening $\left(\mathrm{N} 41^{\circ} 02.211 / \mathrm{E} 116^{\circ} 55.593\right)$. C: Nebulitic diatexite with a disharmonic fold pattern (N4044.860/E114²0.933). D: Within Middle Diatexite, mafic melanosome within more leucocratic neosome that marks decimeter-scale tight folds with horizontal axial-planes, in the top of a dome (N40 $\left.44.404 / \mathrm{E} 114^{\circ} 20.726\right)$. E: Within Middle Diatexite, intrafolial fold outlined by a melanocratic layer within more leucocratic neosome that accounts for transposition of an earlier disrupted compositional migmatitic $\mathrm{S}_{2}$ foliation (N4045.540/E114⒛835). F: Within Middle Diatexite, high strained stromatitic migmatites with a steeply dipping S2 foliation (N40 45.339/E114²0.908).

Figure 5. Geological and structural map of the Datong-Huai'an area (see location in figure 3). 
Figure 6. Geological and structural map of the Xuanhua massif (see location in figure 3).

Figure 7. Geological and structural map of the Chengde massif (see location in figure 3).

Figure 8. Cross-sections throughout the HPB in the Datong-Huai'an area (A), the Xuanhua massif (B) and the Chengde massif (C and D). Insert: location of the cross-sections.

Figure 9. Photographs of $\mathrm{D}_{2}$ and $\mathrm{D}_{3}$ deformation features. A: Syn-anatectic north verging folds with anatectic melt filling the fold axial plane schistosity, in the metatexites developed at the expense of the Orthogneiss-Volcanite Unit (N3907.828/E112 51.078). B: Subsolidus deformation with $\mathrm{S}_{3}$ development parallel to $\mathrm{S}_{2}\left(\mathrm{~N} 40^{\circ} 50.207 / \mathrm{E} 115^{\circ} 41.505\right)$. C: Subsolidus $\mathrm{D}_{3}$ boudinage with preserved $\mathrm{D}_{2}$ fabric within boudins $\left(\mathrm{N} 40^{\circ} 22.600 / \mathrm{E} 114^{\circ} 28.131\right)$.

Figure 10. Photographs of D3 fabric along the Datong-Chengde Shear Zone. A: $\mathrm{S}_{3}$ mylonitic foliation developed in an Al-rich gneiss within the northwestern part of the DCZS (Huai'an area $\left.\left(\mathrm{N} 40^{\circ} 35.164 / \mathrm{E} 113^{\circ} 02.449\right)\right)$. $\mathrm{B}: \quad$ Moderately plunging $\mathrm{L}_{3} \quad$ lineation $\left(\mathrm{N} 41^{\circ} 00.306 / \mathrm{E} 116^{\circ} 25.129\right)$. C: NW-SE trending $\mathrm{L}_{3}$ lineation hold by a flat lying $\mathrm{S}_{3}$ mylonitic foliation, east of Chengde village $\left(\mathrm{N} 41^{\circ} 04.034 / \mathrm{E} 118^{\circ} 19.945\right)$. $\mathrm{D}$ : The $\mathrm{D}_{3}$ mylonitic fabric with top-to-the NW shearing developed during destabilisation of Opx porphyroblasts dynamically recristallized in an assemblage of orthopyroxene + amphibole + plagioclase $\left(\mathrm{N} 41^{\circ} 08.979 / \mathrm{E} 117^{\circ} 39.280\right)$. E: Microphotograph of the mylonitic fabric of the rock of the figure 10D, with the top-to-the NW normal kinematics shown by sigma-type and shear band criteria. 
Figure 11. Combined thermobarometric data and P-T paths for mafic HP granulites within the HPB. The bold gray dotted line is the melt-enhanced geotherm calculated for dehydration melting of a hornblende+quartz $+/-$ plagioclase and considering upward melt migration (Depine et al., 2008)

Figure 12. Compilation and frequency diagrams for $\mathrm{U}-\mathrm{Pb}, \mathrm{Pb}-\mathrm{Pb}, \mathrm{U}-\mathrm{Th} / \mathrm{Pb}$ ages reported from the HPB. A: For the whole dataset (81 ages). B: For ages ranging from 1900 to $1800 \mathrm{Ma}$.

Table 1. Compilation of thermobarometric data recorded for the High-Pressure mafic rocks within the HPB.

Table 2. Geochronological data set of in-situ SHRIMP zircon U-Pb ages (a), U-Th-Pb EPMA monazite ages (b), ICP-MS U-Pb zircons dates (c), (d), and single grain evaporation ${ }^{207} \mathrm{~Pb} /{ }^{206} \mathrm{~Pb}$ ages (e), published for the High-Pressure Belt and adjacent surrounding units. The set is arranged in decreasing order. 


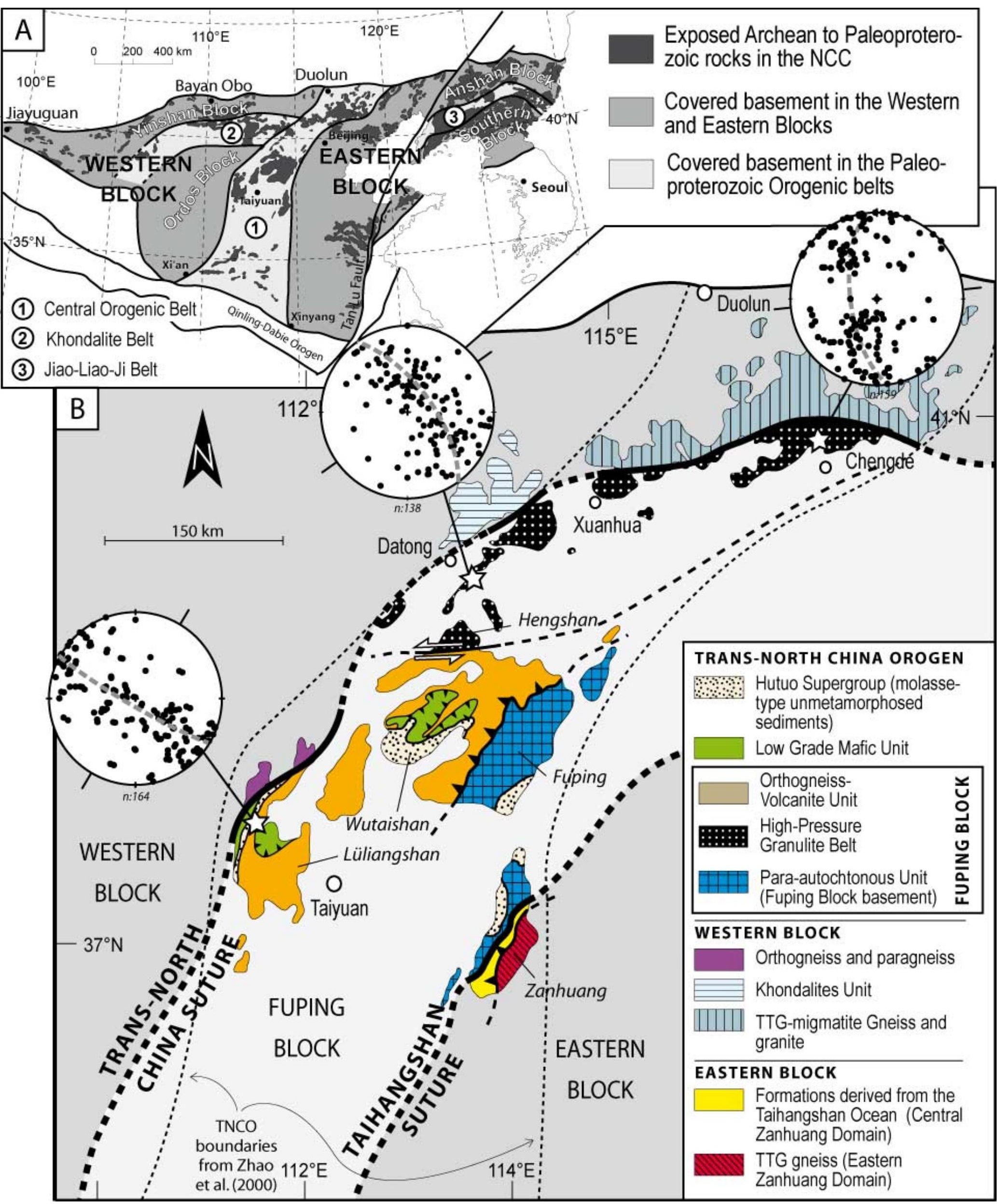




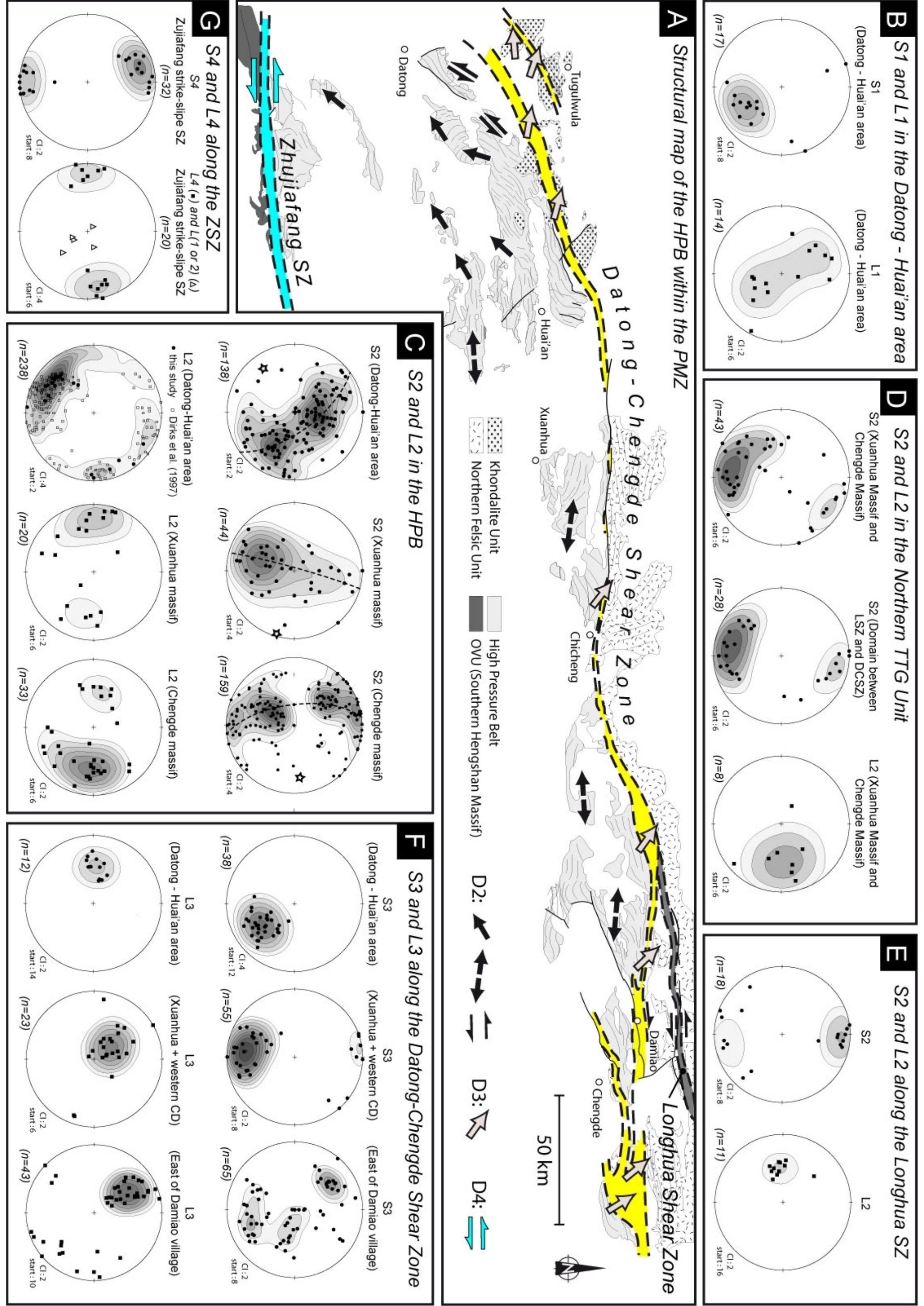




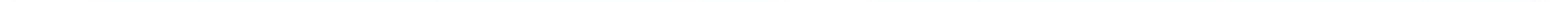




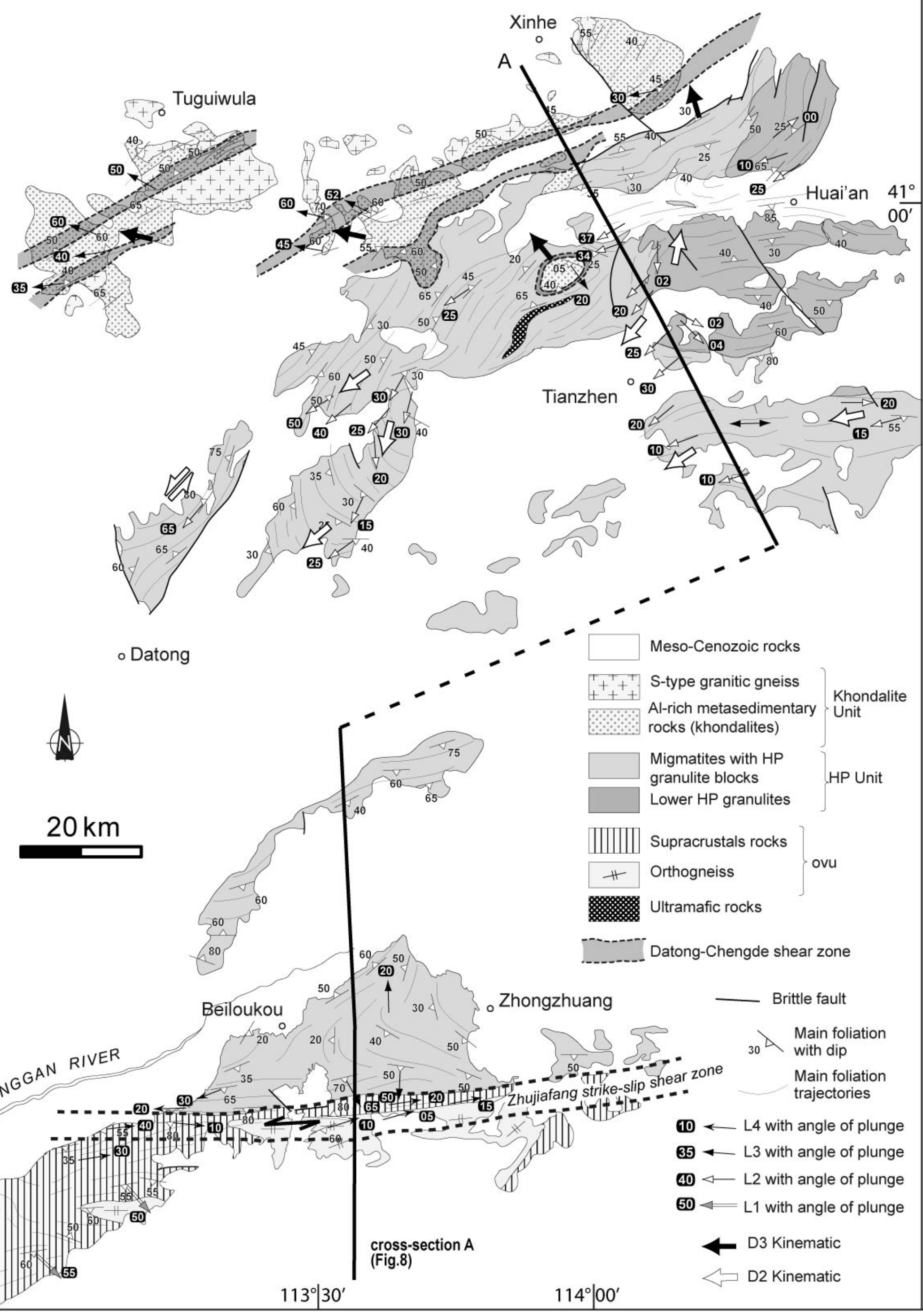

${\frac{40^{\circ}}{20^{\prime}}}^{\prime}$

${\frac{40}{00^{\prime}}}^{\prime}$ 


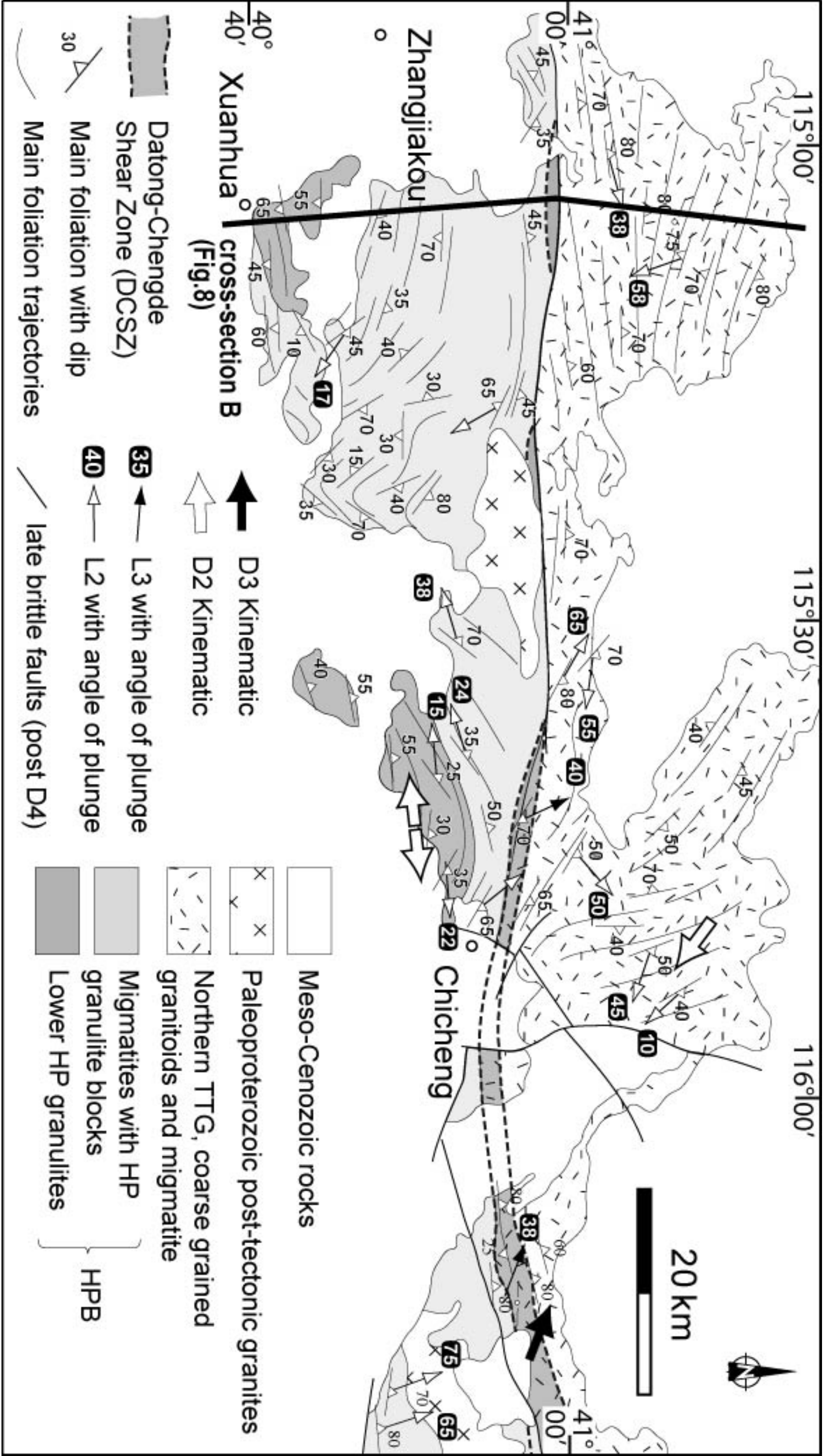




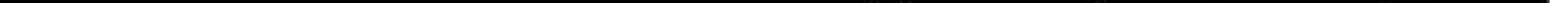




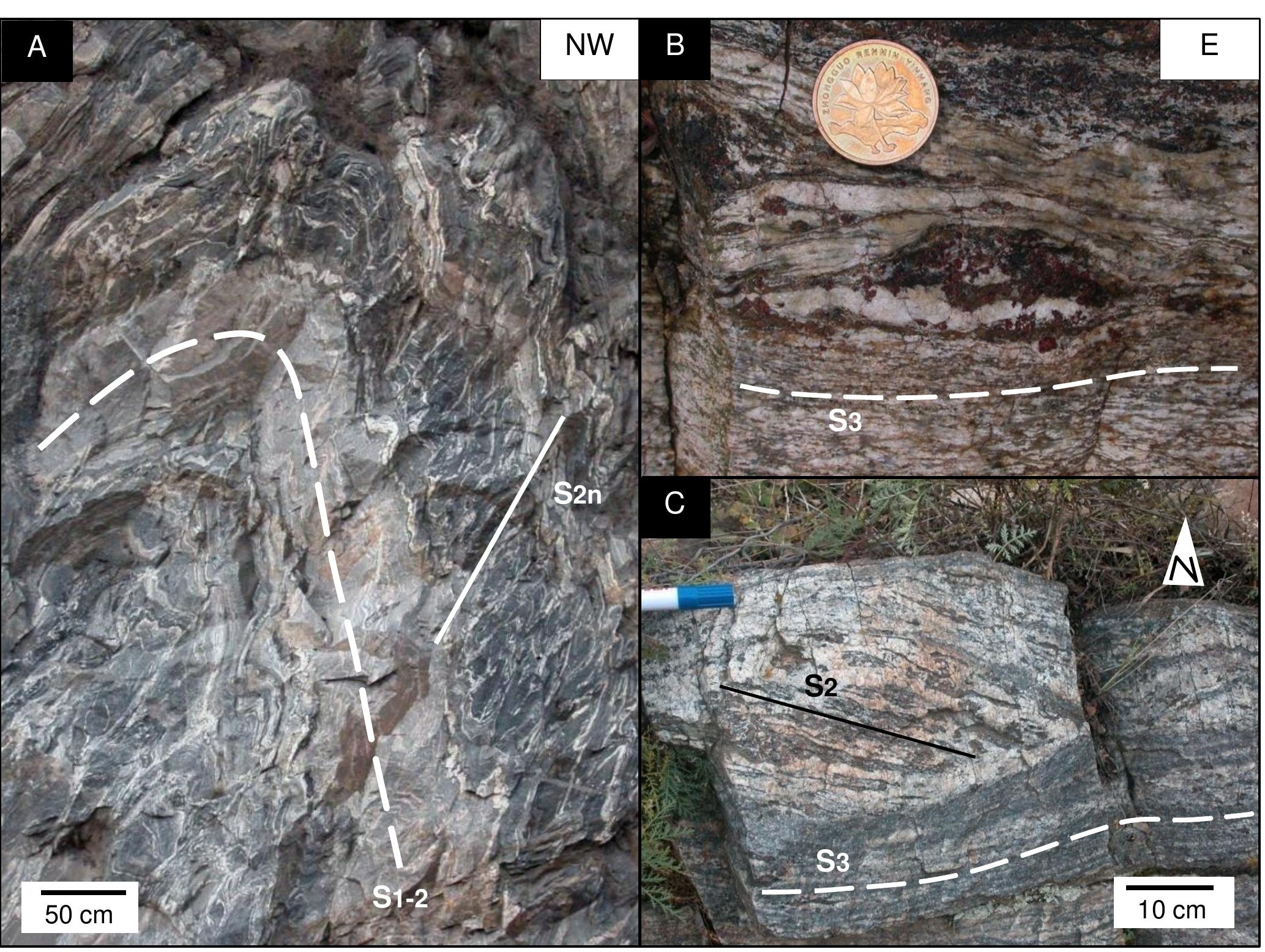




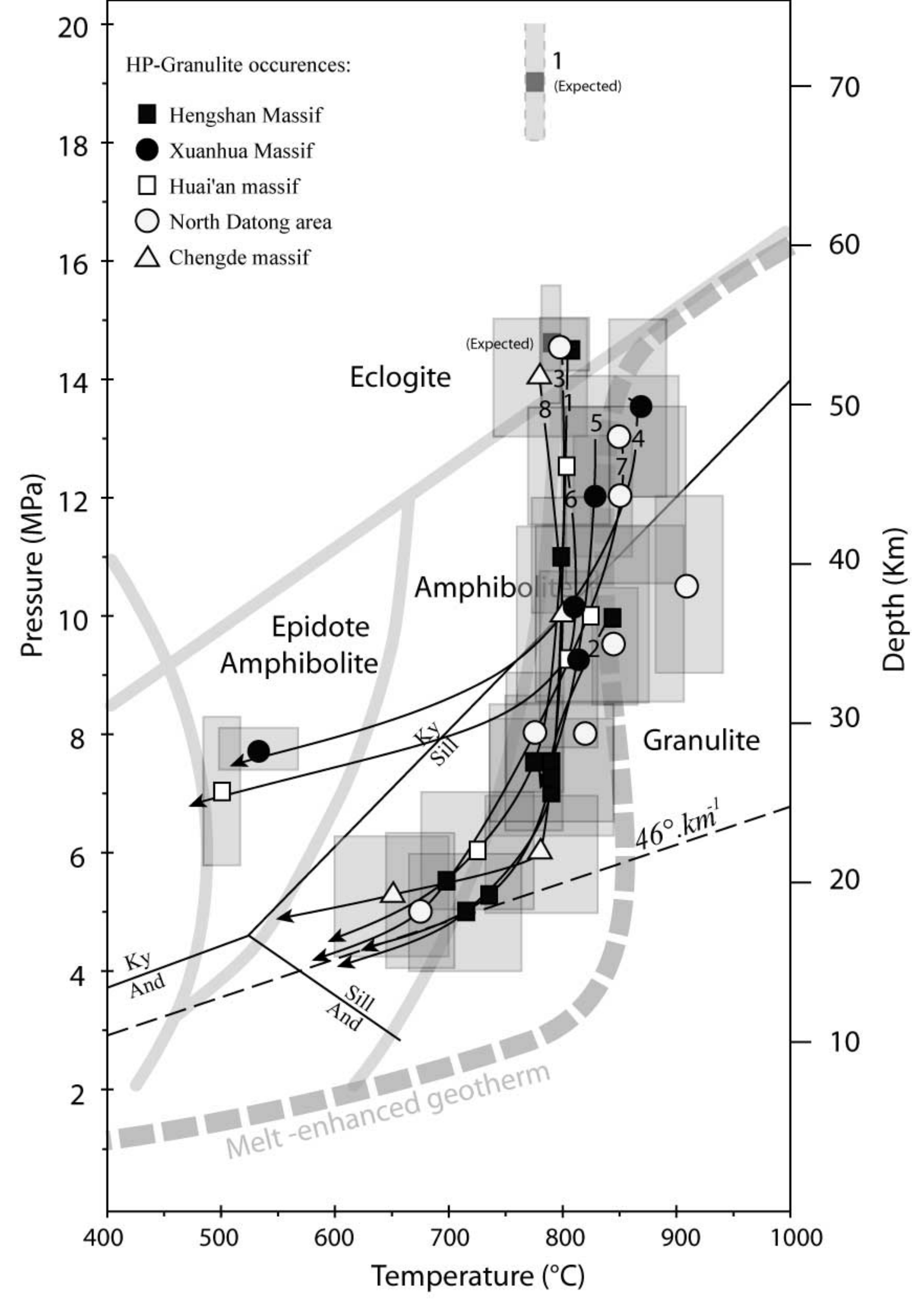




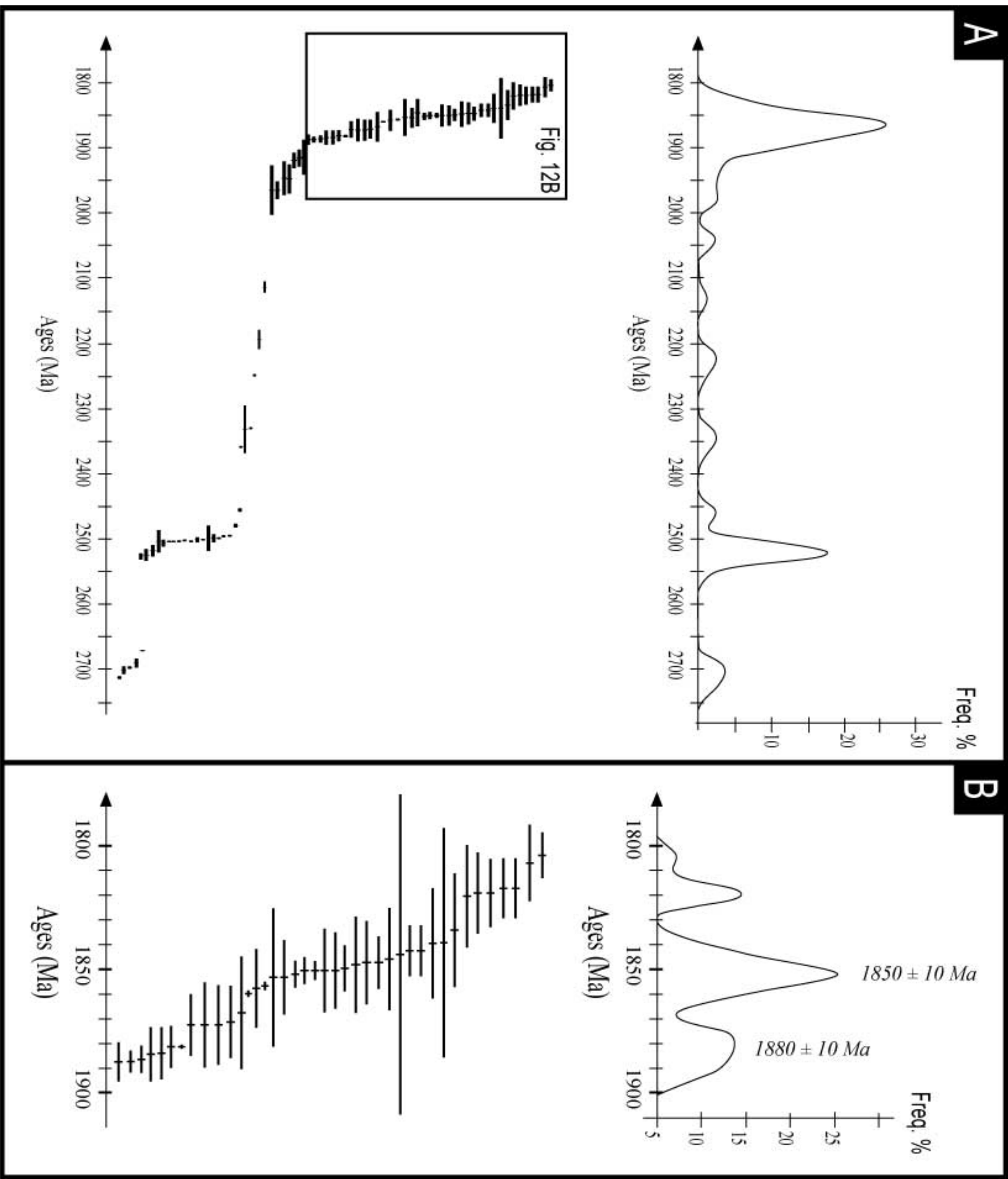


Table 1. Compilation of thermobarometric data recorded for the high-pressure mafic rocks within the HPB.

\begin{tabular}{|c|c|c|c|c|c|c|c|c|c|c|}
\hline Massif & \multirow{2}{*}{\multicolumn{2}{|c|}{$\begin{array}{l}\begin{array}{l}\text { Prograde } \\
\text { assemblage }\end{array} \\
\text { (Inclusion) }\end{array}$}} & \multicolumn{2}{|c|}{ Peak assemblage } & \multicolumn{4}{|c|}{ Retrograde assemblages } & \multirow[t]{3}{*}{ References } & \multirow{2}{*}{$\begin{array}{l}\begin{array}{l}\text { Label } \\
\text { (Fig. 11 }\end{array} \\
\begin{array}{l}\text { (P-T } \\
\text { path) }\end{array}\end{array}$} \\
\hline & & & & & \multicolumn{2}{|l|}{ Early } & \multicolumn{2}{|l|}{ Late } & & \\
\hline & $\begin{array}{l}\text { P, sP } \\
\text { (kbar) }\end{array}$ & $\begin{array}{l}\mathrm{T}, s \mathrm{~T} \\
\left({ }^{\circ} \mathrm{C}\right)\end{array}$ & $\begin{array}{l}\mathbf{P}, s P \\
\text { (kbar) }\end{array}$ & $\begin{array}{l}\mathrm{T}, s T \\
\left({ }^{\circ} \mathrm{C}\right)\end{array}$ & $\begin{array}{l}\mathbf{P}, s P \\
\text { (kbar) }\end{array}$ & $\begin{array}{l}\mathrm{T}, s T \\
\left({ }^{\circ} \mathrm{C}\right)\end{array}$ & $\begin{array}{l}\mathbf{P}, s P \\
\text { (kbar) }\end{array}$ & $\begin{array}{l}\mathrm{T}, s \mathrm{~T} \\
\left({ }^{\circ} \mathrm{C}\right)\end{array}$ & & \\
\hline \multirow[t]{6}{*}{$\begin{array}{l}\text { North } \\
\text { Hengshan } \\
\text { Massif }\end{array}$} & & & $(18-20)$ & $(>750)$ & & & & & $\frac{\text { Zhao et al. }}{\underline{(2001 a)}}$ & \\
\hline & & & $\begin{array}{l}13.4- \\
15.5 \\
1.5\end{array}$ & $\begin{array}{l}770-840 \\
50\end{array}$ & $6.5-8,1$ & $\begin{array}{l}750- \\
830,40\end{array}$ & $\begin{array}{l}4.5-6, \\
1.2\end{array}$ & $\begin{array}{l}680- \\
790,60\end{array}$ & $\begin{array}{l}\text { In Zhang et al. } \\
\text { (2006) }\end{array}$ & 1 \\
\hline & & & $(14-15)$ & $(>800)$ & & & & & $\frac{\text { O'Brien et al. }}{\underline{(2005)}}$ & \\
\hline & & & $>11$ & $>800$ & $7-8$ & $\begin{array}{l}750- \\
800\end{array}$ & $5-6$ & $\begin{array}{l}650- \\
700\end{array}$ & - & 2 \\
\hline & & & & & $\begin{array}{l}7-8, \\
0.5-1.5\end{array}$ & $\begin{array}{l}730- \\
850 \\
20-60\end{array}$ & & & Zhao et al. (2000) & \\
\hline & & & $\begin{array}{l}9-11 \\
0.5-1.5\end{array}$ & $\begin{array}{l}820-870 \\
20-60\end{array}$ & $\begin{array}{l}6.5-7.5 \\
0.5-1\end{array}$ & $\begin{array}{l}740- \\
840 \\
20-50\end{array}$ & $\begin{array}{l}4-6 \\
0.5-1\end{array}$ & $\begin{array}{l}680- \\
750 \\
20-40\end{array}$ & $\underline{\text { Zhao et al. (2000) }}$ & 3 \\
\hline \multirow[t]{2}{*}{$\begin{array}{l}\text { Xuanhua } \\
\text { Massif }\end{array}$} & & & $12-15$ & $840-890$ & $9-11$ & $\begin{array}{l}780- \\
850\end{array}$ & $7.5-8.0$ & $\begin{array}{l}500- \\
570\end{array}$ & $\underline{\text { Guo et al. (2002) }}$ & 4 \\
\hline & & & $11-13$ & $810-860$ & $8-10$ & $\begin{array}{l}780- \\
850\end{array}$ & & & - & 5 \\
\hline \multirow[t]{2}{*}{$\begin{array}{l}\text { East Datong- } \\
\text { Huai'an } \\
\text { Massif }\end{array}$} & 9-12 & $\begin{array}{l}680- \\
750\end{array}$ & $11-14$ & $780-830$ & $9-10.5$ & $\begin{array}{l}790- \\
820\end{array}$ & $6.5-7.5$ & $\begin{array}{l}570- \\
630\end{array}$ & $\underline{\text { Guo et al. (2002) }}$ & 6 \\
\hline & 8,1 & $\begin{array}{l}650 \\
50\end{array}$ & 10,1 & 825,50 & 6,1 & 725,50 & & & $\underline{\text { Liu (1995) }}$ & \\
\hline \multirow[t]{3}{*}{$\begin{array}{l}\text { West Datong- } \\
\text { Huai'an } \\
\text { Massif }\end{array}$} & $12-14$ & $\begin{array}{l}800- \\
900\end{array}$ & $10-14$ & $800-900$ & $7-9$ & $\begin{array}{l}750- \\
800\end{array}$ & $5-6$ & $\begin{array}{l}650- \\
700\end{array}$ & $\underline{\text { Zhang et al. }}$ & 7 \\
\hline & & & $9-12$ & $880-940$ & $9.5,1$ & 845,20 & & & $\begin{array}{l}\text { Liu (1989) and } \\
\underline{\text { Liu et al. (1993) }}\end{array}$ & \\
\hline & & & $14-15$ & 800,20 & $7-9$ & 820,20 & & & $\begin{array}{l}\text { Zhai et al. (1992) } \\
\text { and Guo et al. } \\
\underline{(1993)}\end{array}$ & \\
\hline $\begin{array}{l}\text { Chengde } \\
\text { Massif }\end{array}$ & $13-15$ & $\begin{array}{l}760- \\
800\end{array}$ & $8-10$ & $780-820$ & $5-7$ & $\begin{array}{l}760- \\
800\end{array}$ & $4-6.5$ & $\begin{array}{l}620- \\
680\end{array}$ & $\underline{\text { Li et al. (1998) }}$ & 8 \\
\hline
\end{tabular}


Table 2. Geochronological data set of in-situ SHRIMP zircon U-Pb ages (a), U-Th-Pb EPMA monazite ages (b), ICP-MS U-Pb zircon dates (c), (d), and single grain evaporation ${ }^{207} \mathrm{~Pb} /{ }^{206} \mathrm{~Pb}$ ages (e), published for the High-Pressure Belt and adjacent surrounding units. The set is arranged in decreasing order.

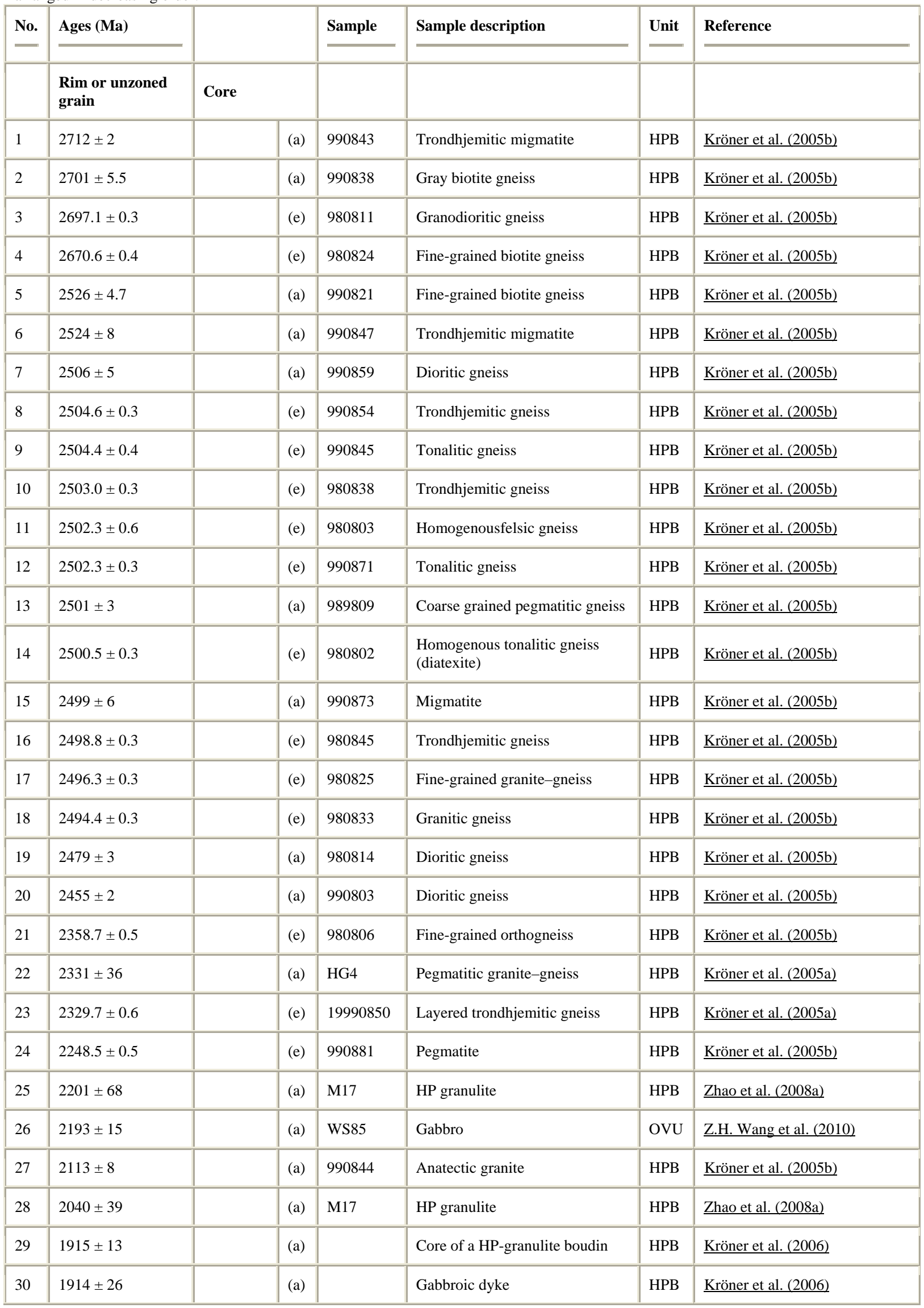




\begin{tabular}{|c|c|c|c|c|c|c|c|}
\hline No. & Ages (Ma) & & & Sample & Sample description & Unit & Reference \\
\hline & $\begin{array}{l}\text { Rim or unzoned } \\
\text { grain }\end{array}$ & Core & & & & & \\
\hline 31 & $1887 \pm 8$ & $1919 \pm 12$ & (b) & FP359 & Sill-bearing micaschist & OVU & Trap et al. (2009a) \\
\hline 32 & $1887 \pm 4$ & & (b) & W109 & Grt-St-bearing micaschist & OVU & Trap et al. (2007) \\
\hline 33 & $1886 \pm 5$ & & (b) & W175 & Grt-St-Ky-bearing gneiss & OVU & $\underline{\text { Trap et al. (2007) }}$ \\
\hline 34 & $1884 \pm 11$ & & (b) & H29 & Grt-St-Ky-bearing gneiss & $\mathrm{OVU}$ & Trap et al. (2007) \\
\hline 35 & $1883 \pm 11$ & & (b) & FP35 & Bt-Grt-Ky-St gneiss & OVU & $\underline{\text { Faure et al. (2007) }}$ \\
\hline 36 & $1881 \pm 8$ & & (a) & 990803 & Dioritic gneiss & HPB & Kröner et al. (2005b) \\
\hline 37 & $1881 \pm 0.4$ & & (a) & & HP granulite & НРВ & $\underline{\text { Kröner et al. (2006) }}$ \\
\hline 38 & $1872 \pm 12$ & & (b) & FP360 & Sill-bearing micaschist & OVU & Trap et al. (2009a) \\
\hline 39 & $1872 \pm 17$ & & (a) & HG1 & $\begin{array}{l}\text { Granitic gneiss-migmatitic } \\
\text { leucosome }\end{array}$ & HPB & $\underline{\text { Kröner et al. (2005b) }}$ \\
\hline 40 & $1872 \pm 16$ & & (a) & XW22 & HP granulite & НРВ & $\underline{\text { Guo et al. (2005) }}$ \\
\hline 41 & $1871 \pm 14$ & & (a) & TWJ358/1 & Grt bearing orthogneiss & НРB & $\underline{\text { Wan et al. (2006) }}$ \\
\hline 42 & $1867 \pm 23$ & & (a) & HG2 & HP granulite mafic dyke boudin & НРВ & $\underline{\text { Kröner et al. (2005b) }}$ \\
\hline 43 & $1859.7 \pm 0.5$ & & (e) & & Mafic retrograded eclogite & НРB & $\underline{\text { Kröner et al. (2006) }}$ \\
\hline 44 & $1857 \pm 16$ & $1947 \pm 22$ & (a) & 06M02 & Cordierite-Grt-FK granulite & НРB & $\underline{\text { Zhao et al. (2010) }}$ \\
\hline 45 & $1856.1 \pm 0.6$ & & (e) & & $\begin{array}{l}\text { Melt patche within gabbroic } \\
\text { boudin }\end{array}$ & HPB & Kröner et al. (2006) \\
\hline 46 & $1853 \pm 28$ & $2503 \pm 17$ & (a) & 08MQG30 & TTG gneiss & НРВ & J. Wang et al. (2010) \\
\hline 47 & $1853 \pm 15$ & $1964 \pm 13$ & (a) & 08MQG22 & Migmatitic khondalite (neosome) & НРВ & J. Wang et al. (2010) \\
\hline 48 & $1851 \pm 5$ & & (a) & Ch990839 & $\begin{array}{l}\text { Melt patche within gabbroic } \\
\text { boudin }\end{array}$ & HPB & $\underline{\text { Kröner et al. (2005b) }}$ \\
\hline 49 & $1850 \pm 5$ & $2686 \pm 7$ & (c) & FP52 & Migmatitic leucosome & НРВ & Faure et al. (2007) \\
\hline 50 & $1850 \pm 3$ & & (a) & M068 & HP-retrograded eclogite & НРВ & $\underline{\text { Kröner et al. (2005b) }}$ \\
\hline 51 & $1850 \pm 17$ & & (a) & M24 & $\begin{array}{l}\text { Dapinggou garnet-bearing S-type } \\
\text { granite }\end{array}$ & НРВ & $\underline{\text { Zhao et al. (2008a) }}$ \\
\hline 52 & $1850 \pm 15$ & $1946 \pm 26$ & (a) & 01M20 & Graphite-Grt-Sill gneiss & НРВ & Zhao et al. (2010) \\
\hline 53 & $1849 \pm 9.8$ & & (a) & M22 & $\begin{array}{l}\text { Anatectic charnokite (Huai'an } \\
\text { charnokite) }\end{array}$ & НРВ & Zhao et al. (2008a) \\
\hline 54 & $1848 \pm 19$ & & (a) & M17 & HP mafic granulite & НРВ & Zhao et al. (2008a) \\
\hline 55 & $1847 \pm 17$ & $2515 \pm 20$ & (a) & M21 & Tonalitic gneiss & НРВ & Zhao et al. (2008a) \\
\hline 56 & $1847 \pm 11$ & $2440 \pm 26$ & (a) & M23 & Granodioritic gneiss & HPB & $\underline{\text { Zhao et al. (2008a) }}$ \\
\hline 57 & $1844 \pm 66$ & & (a) & TW0006/1 & Graphite-Grt-Sill gneiss & НPB & Wan et al. (2006) \\
\hline 58 & $1842 \pm 10$ & $2499 \pm 19$ & (a) & M19 & Trondhjemitic gneiss & НРВ & $\underline{\text { Zhao et al. (2008a) }}$ \\
\hline 59 & $1842 \pm 10$ & \pm & (a) & 08MQG23 & Migmatitic khondalite (neosome) & НРВ & J. Wang et al. (2010) \\
\hline 60 & $1839 \pm 22$ & $1964 \pm 38$ & (a) & 08MQG26 & HP mafic granulite & HPB & J. Wang et al. (2010) \\
\hline
\end{tabular}




\begin{tabular}{|c|c|c|c|c|c|c|c|}
\hline No. & Ages (Ma) & & & Sample & Sample description & Unit & Reference \\
\hline & $\begin{array}{l}\text { Rim or unzoned } \\
\text { grain }\end{array}$ & \multicolumn{2}{|l|}{ Core } & & & & \\
\hline 61 & $1839 \pm 46$ & $2036 \pm 16$ & (a) & M28 & Granitic gneiss & HPB & Zhao et al. (2008a) \\
\hline 62 & $1833 \pm 23$ & & (d) & & HP mafic granulite & НРВ & $\underline{\text { Guo et al. (1994) }}$ \\
\hline 63 & $1820 \pm 21$ & & (d) & & Charnockite & HPB & $\underline{\text { Guo et al. (1994) }}$ \\
\hline 64 & $1819 \pm 16$ & & (a) & XW23 & HP granulite & HPB & $\underline{\text { Guo et al. (2005) }}$ \\
\hline 65 & $1819 \pm 13$ & $1846 \pm 21$ & (a) & 08MQG28 & Leucosome og migmatitic TTG & HPB & $\begin{array}{l}\text { (Wang et al., 2010a) and (Wang } \\
\underline{\text { et al., 2010) }}\end{array}$ \\
\hline 66 & $1817 \pm 12$ & & (a) & MJ36 & HP granulite & HPB & $\underline{\text { Guo et al. (2005) }}$ \\
\hline 67 & $1817 \pm 12$ & & (a) & MJ35 & HP granulite & HPB & Guo et al. (2005) \\
\hline 68 & $1806 \pm 15$ & & (a) & 08MQG29 & FK + Q pegmatite dyke & НPB & $\begin{array}{l}\text { (Wang et al., 2010a) } \\
\underline{\text { et al., 2010) }}\end{array}$ \\
\hline 69 & $1803 \pm 9$ & & (a) & XW22 & HP granulite & HPB & Guo et al. (2005) \\
\hline
\end{tabular}

